University of Louisville

ThinkIR: The University of Louisville's Institutional Repository

Electronic Theses and Dissertations

1943

\title{
The Christmas story in American literature.
}

Katharine Allyn See

University of Louisville

Follow this and additional works at: https://ir.library.louisville.edu/etd

Part of the Literature in English, North America Commons

\section{Recommended Citation}

See, Katharine Allyn, "The Christmas story in American literature." (1943). Electronic Theses and Dissertations. Paper 2167.

https://doi.org/10.18297/etd/2167

This Master's Thesis is brought to you for free and open access by ThinkIR: The University of Louisville's Institutional Repository. It has been accepted for inclusion in Electronic Theses and Dissertations by an authorized administrator of ThinkIR: The University of Louisville's Institutional Repository. This title appears here courtesy of the author, who has retained all other copyrights. For more information, please contact thinkir@louisville.edu. 


\title{
UN IVERS ITY OF LOUISVIIIE
}

THE CHRISTMAS STORY IN AMERICAN LITERATURE

\author{
A Dissertation \\ Submitted to the Faculty \\ of the Graduate School of the University of Louisvilie \\ In Partial Fulfiliment of the \\ Requirements for the Degree \\ of Master of Arts
}

Department of English

By

KATHARINE ALIYN SEE

Year

1943 
NAME OF STUDENT:

Katharine Allyn See

TITLE OF THESIS: The Christran Stoy die

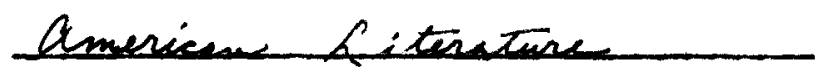

APPROVED BY READING COMMITTEE COMPOSED OF THE FOLLOWING MEMBERS:

Ernest C. Hassold

Mary E. Burton

James Morgan Read

NAME OF DIKECHOR: $\quad$ Ernest C. Hassold

DATE: Inay 19,1943 
3

s 


\section{INTRODUCTION}

This investigation had its origin in a personal interest in the Iiterature of Christmas. For a number of years the writer has been playing with the idea of compiling an anthology of Christmas stories.

The existence of a large body of Christmas fiction, and the absence of any systematic investigation, 1 indicated the desirability of exploring the field, in order to locate the best specimens, and to answer two basic questions:

1. Is the Christmas story an Independent Iiterary genre?

2. What is the course of its development in American Iiterature?

This study is based, first, on the Christmas material in three leading American magazines, 2 from their foundation to the present time; this sample was then supplemented by the Christmas stories of some ten American authors, beginning with Washington Irving.

1 The treatment of the subject by E. Douglas Branch, to which frequent reference is made, and to which the writer is indebted for suggestions, does not explore the problems raised by this thesis.

2 Harper's Magazine, founded 1851; The Atlantic Monthly, founded 185\%; Scribner's Magazine, founded 1887. 
The sample is Iimited to American stories, 1 of adult level.2 The time covered extends from the publication of Irving's Sketch Book (1819-1820) to the First World War.3 An examination of the stories showed that they fell naturally into two periods, or cycles, of three divisions each: the first extending roughly from the publication of the Sketch Book until the war between the states; and the second terminating with the First world War. The study is organized on the basis of this historical development. The early development of the Christmas story in the work of Irving, Dickens, and Hawthorne demanded a fuller examination than was required for the stories of most of the later writers. The fusion of the Christmas story with the local color story, occurring early in the second period, has been demonstrated by the analysis of representative selections. Only two writers of this period, Henry van Dyke and James Lane Allen, contributed fresh features which called

I The consideration of Dickens does not violate this restriction, as his work is viewed only in its interrelation with that of Irving and Hawthorne, and in its influence on subsequent American Christmas fiction.

2 one of the best known American Christmas stories, The Birds' Christmas Carol, by Kate Douglas Wiggin, must be 3 The investigation disclosed little outstanding material published since that time. 
for more detalled investigation.

This study makes no attempt to constitute an exhaustive treatment of the subject. The writer does believe that the solection of the materials has been sufficiently representative to define the Christmas story as a minor literary genre, and to trace its progress in American literature. 


\section{TABLE OF CONTENTS}


TABLE OF CONTENTS

CHAPTER

PAGE

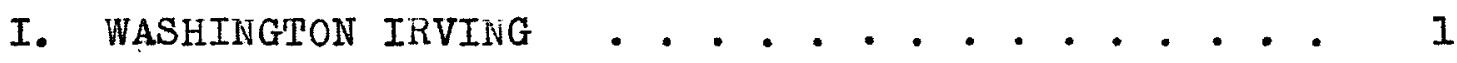

Sketch Book: Background and Character .... I 1

Sketch Book: Its Influence . . . . . . . 6

Irving and Dickens: A Comparison ...... II

II. CHARLES DICKENS: A CHRISTPAS CAROL ...... 21

The Carol: Its Background ......... 21

The Garol: Its Influence ......... 24

III. NATHANIEL HAWTHORNE . . . . . . . . . 31

The Christmas Banquet ........... 31

Hawthorne and Dickens... . . . . . 35

IV. CHRISTMAS IN THE AMERICAN SCENE ........ 43

Christmas in the Local Color Story . . . . . 43

The Christmas Story Goes West . . . . . . 45

Christmas in the Story of the South . . . . 47

The Christmas Story in Now England ..... 53

The Christmas Story Surveys the Slum .... 58

The Christmas Story Along a French By-Path . . 61

V. HENRY VAN DYKE: THE RELIGIOUS EMPHASIS . . . . 65

VI. JAMES LANE ALLEN: ACCENT ON CHILI. . . . . . 78

VII. CONCLUSIONS .............. 94

CHRONOLOGICAL LIST: CHRISTMAS FICTION . . . . . . 99 BIBLIOGRAPHY . . . . . . . . . . . . . . 111 APPENDIX . . . . . . . . . . . . . . 120 
CHAPTER I

WASHINGTON IRVING 


\section{WASHINGTON IRVING}

So long as the celebration of Christmas remained a negligible quantity in American life, there was, naturally, no Christmas ilterature. In New England, the Puritans had soleming forsworm the day; even in Virginia, such a hedonist as William Byrd makes no mention of celebration other than attending church.1

It remained for the Dutch settlers in New York to set the stage for our modern Yuletide, through their cheerful cult of st. Nicholas, which gradually became merged with the English Christmas. It is significant that when, about 1820, Christmas made 1 ts appearance in the works of three writers, all three were from the center, not of Boston, but of New York. The three works were "A V1sit from St. Nicholas," by Clement Clark Moore; the opening chapters of The Pioneers, by James Fenimore Cooper; and the Christmas chapters of The Sketch Book of Geoffrey Crayon, Gent., by Washingt on Irving.

The Sketch Book: Background and Character. "The enormous success of Irving," says Pattee, ". . with his

1 William Byrd, The Secret Diary of William Byrd of Westover, 1709-1712, Louis B. Wright and Marion TinI1ng, 
Sketch Book and his Bracebridge Hall, set the literary bells ringing all over America."I A careful study of the Sketch Book might lead one to wonder whether those bells might not have been Christmas bells, echoing on both sides of the Atlantic.

The Christmas chapters in the Sketch Book are not short stories. Indeed, the expression used by an English critic in praising one of the other essays in the book, "It 1s, I believe, all tme," is the very claim which Irving himself made for the Christmas sketches, in defonding them against the charge of being out of date: "The author had afterwards an opportunity of witnessing almost all the customs above described." Notwithstanding, Irving was skilful enough not to describe the customs in mere catalogue fashIon, but to string them together with a slight narrative. Moreover, to find them all together in one household, the fiction of Squire Bracebridge was necessary.

In several ways Irving was conditioned to appreciate the English Christmas. In the first place, he would have

1 Fred Lewls Pattee, The First Century of American Literature: 1770-1870 (New York: D. Appleton-Century Co., Inc., 1934), p. 396.

2 Washington Irving, The Sketch Book of Geoffrey Crayon, Gent. (New York: G. P. Putnam \& Co. . 185\%), p. 298. All following references are to this edition. However, the Christmes chapters have been compared with the 1834 edition and found identical. 
been made receptive because of the New York Dutch St. Nicholas, who was gradually becoming identified with the colebration of Christmas. St. Nicholas appears time and again throughout the pages of Knickerbocker. The ship bearing the first "honest Dutch lowlanders" had as Its figurehead an Image of the good saint, with "a pipe that reached to the end of the bowsprit." I Later, a vision of St. N1cholas pointed out the site of the city. ${ }^{2}$ Promptly the settlers

- bethought themselves of testifying their gratitude to the great and good st. Nicholas for his protecting care, in guiding them to this delectable abode. Ho this end they built a fair and goodly chapel within the fort, which they consecrated to his name; whereupon he immediately took the town of New Amsterdam under his peculiar patronage, and he has even since been, and I devoutly hope ever will be, the tutelar saint of this excellent city.

At this early period was instituted that pious ceremony $;$ of hanging up a stocking in the chimney on St. Nicholas eve. 3

An interesting connection of Irving with American Christmas is that with Clement Clark Moore. That they moved in the same circles is evident from a letter of Miss Falrlie to Irving, in 1807, describing a "conversazione" which she

1 Washington Irving, A History of New-York . - by Diedrich Knickerbocker [pubišshed 1809] (New York: G. P. Petnam \& Co., 1857), pp. 86-88.

2 op. c1.t. pp. 96, 115.

3 op. c1t., pp. 130-31. 
had attended, at which Moore was guest of honor. 1 surely Moore's portrait of St. Nicholas, who "flew to the housetops," whose "smoke encircled his head," and who "Iaid a finger aside of his nose," must derive something from the following Knickerbocker description:

And the sage 0loffe dreamed a dream--and 10, the good St. Nicholas came riding over the tops of the trees in that self-same wagon wherein he brings his jearly presents to children. . And as he smoked the smoke of his pipe ascended into the air and spread like a cloud overhead . - And when St. Nicholas had smoked his pipe, he twisted it in his hat band, and laying a finger beside his nose, gave the astonished Van Kortlandt a very significant look, then mounting his wagon, he returned over the tree-tops and disappeared.2

But the English Christmas is something entirely dif-

ferent; and this, too, Irving was prepared to appreciate, because of the fascination the old World held for him:

I was always fond of visiting new scenes, and observing strange characters and manners...

Europe held forth the charms of storied and poetical association. . I longed ... to escape... from the commonplace realities of the present, and lose myself among the shadowy grandeurs of the past. 3

Nothing in England exercises a more delightful spell over my imagination, than the lingering of the holiday customs. - of former times. They recall the pictures my fancy used to draw in the May morning of $11 f \theta$, when

1 George S. Hellman, Washington Irving, Esquire: Ambassador at Large erom the New World to the old (New York: Alfred A. KnopI, 1925), p. 59.

2 Irving, Knickerbocker, p. 115.

3 Irving, Sketch Book, pp. 9, 10-11. 
as yet I only knew the world through books, and believed It to be all that poets had painted it; and they bring with them the flavor of those honest days of yore, in which, perhaps; with equal fallacy, I am apt to think the world was more homebred, social, and joyous than at present . .

of all the old festivals, however, that of Christmas awakens the strongest and most heartfelt associations.1

These sketches have no more profound purpose than to record Irving's own pleasure, and to create pleasure t'or the reader. Their prevaling tone is as warm as the spiced wines in the Bracebridge wassail bowl. A gourmet and not a gourmand, Irving samples the food, the firelight and the fellowship of the Bracebridge Christmas, and finds them good. This sensate treatment of the plcturesque elements of the celebration of Christmas is one which appears frequently in later Christmas fiction, notably in the stories of the local color group.

Furthermore, Irving introduces in these sketches the theme of warmth which is to become the dominant psychological motif of the American Christmas story. Although the physical and spiritual chill implied in his statements that the weather is very cold, 2 and that the writer is far from home and a stranger, 3 is not very convincing, these refer-

$$
\begin{aligned}
& 1 \text { Irving, Sketch Book, pp. 233-34. } \\
& 2 \text { op. cit., p. } 249 . \\
& 3 \text { op. cit., p. } 239 .
\end{aligned}
$$


ences nevertheless represent a deliberate attempt at the contrast of warmth and cold seemingly inherent in the EngI1sh concept of Christmas, and by inheritance in the American concept. As Chesterton forcefully expresses 1t:

- Christmas comfort is the reverse of a gross or material thing . . . It is . . artistic because it is based upon a contrast, a contrast between the fire and wine within the house and the winter and the roaring rains without. It is... poetical because there is in it a note of defenoe, almost of war.. To our good dreams this dark and dangerous background is essential. 1

This image, of warmth at the center, and the menacing cold In the background, is the traditional one. A less optimistic writer will occasionally reverse the picture, presenting it as a photographic negative, with the cold at the center, and the warmth of the traditional Christmas serving as a foll. Such an ironic treatment, however, differs only in emphasis; the writer still acknowledges the traditional dualism.

\section{The Sketch Book: Its Influence. Irving's Christmas} sketches appear to have had little immediate effect on Christmas flction in America. As Branch comments:

The genteel dilettante's love of pretty old ways... could hardiy affect the manners of a people whose

1 G. K. Chesterton, Charles Dickens, A Critical

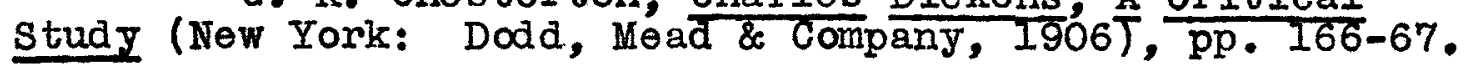


Squires were generally village justices of the peace.1 This criticism, a just one as regards direct influence, overlooks the possibility of an indirect, yet vital, influence. Irving in his readiness to enjoy to the full his English experiences was able, by his fresh viewpoint and his enthusiasm, to make them vivid to his English readers also. Hellman observes: "Thus, in 'l'he Sketch Book' . . Irving - - revealed to England, as no forelgner had ever done before, the soul of England." 2 He quotes Wllliam Godwin's praise of the essay "Rural Iife in England": "It is, I belleve, all true . . and one wonders, whlle reading, that nobody ever said this before."3 Miss Hitford, whose own sketches appeared between 1824 and 1832, wrote in her "Bramley Maying": "Mr. Geoffrey urayon has, in his delightful but somewhat fanciful writings, brought into general view many old sports and customs."4 George William Curtis notes: "Only an American could have seen England as he described 1t, and invested it with an enchantment which the mass of

1 E. Douglas Branch, "Jingle Bells: Notes on Christmas in American Iiterature," Saturday keview of Literature, 17 (December 4, 1937), p. 3.

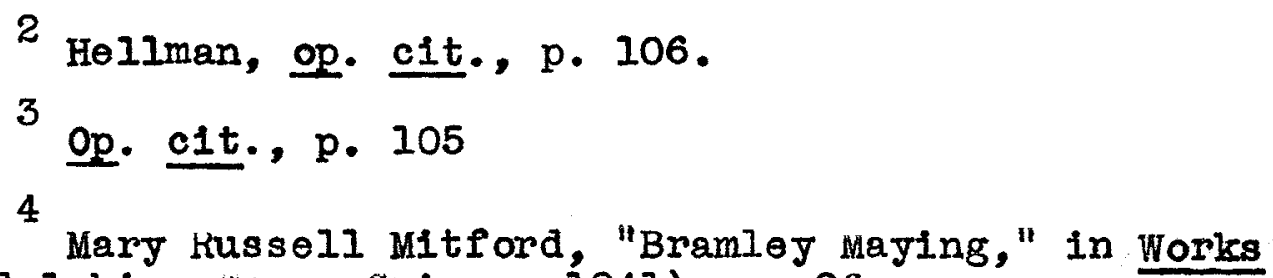


Englishmen had nelther suspected nor perceived."I

In the present study it is relevant to inquire only whether these sketches have any connection with Dickens, especially with Dickens' Christmas stories. Although we are accustomed to thinking of Dickens as deriving his material from the life about him exclusively, nevertheless he must have had some literary sources also. A study of his relations with Irving provides some extermal evidence of one such source; and a comparison of the Christmas chapters in The Pickwick Papers with those in The Sketch Book provides internal evidence.

In the first place, Irving was one American whom Dickens greatly admired, and whose writings he admired. Knickerbocker was a special favorite.2

It was Irving who, of all Americans, most attracted Dickens to the United States. "Everything you have written," Dickens tells Irving, "is in $\mathrm{my}$ thoughts and in my heart of hearts." 3

In 1841, a letter from Irving praising Little Nell strength-

1 George William Curtis, "Washington Irving," in Literary and Social Essays (New York: Harper \& Brothers, 1904), p. 284.

2 Hellman, op. cit., pp. 239-40. Stanley T. Williams, The Life of Washington Irving (New York: Oxford University Press, I935), I, III, 116; II, 116. William Glyde Wilkins, Charles Dickens in America (New York: Charles Scribner's Sons, I912), pp. I27-29.

3 Heliman, op. cit., p. 239. 
ened Dickens' desire to visit America. 1 During his visit to the United States in 1842 he shared honors with Irving without jealousy. ${ }^{2}$ His praise of the American writer, at the Dickens Dinner in New York, is too fulsome for accuracy as a gauge of his feelings; but it is obviously simple exaggeration, not falsehood. 3

Moreover, Dickens had no aversion to using a literary form which Irving had popularized. About 1840 "Dickens expressed a readiness to go.. . to Ireland or America, and to write thence a series of descriptive papers... In the manner of Washington Irving's 'Alhambra. "14

In his The Short Story in English Henry Seldel Canby makes two unrelated observations which, taken together, suggest a second-hand influence:

Our Village, by Miss Mitford . . is a series of sketches. - It is of the Irving of The Sketch Book and Bracebridge Hall that these sketches .. are reminiscent.

$\therefore$ Sketches by Boz are short descriptive narratives,

1 Frederic George Kitton, Charles Dickens: His Life,

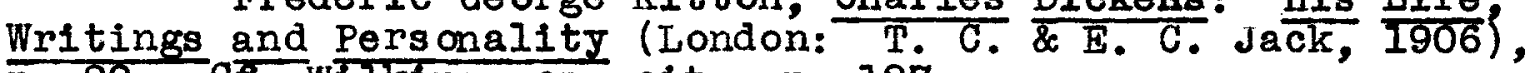
p. 89. Cr. Wilkins, op. c1t., p. 127.

2 Williams, op. cit., II, 117.

3 Wilkins, op. cit., pp. 127-29.

4 Kitton, op. c1t., pp. 74-75. 
Influenced, perhaps, by Miss Mitford's character studies in our viliage. ${ }^{1}$

George William Curtis, who sat at the speakers' table at the Dickens Dinner in New York in 1868,2 regularly coup-

les the two names:

It was Irving who recalled the old English Christmas. It was his cordial and picturesuue description of the great holiday of Christendom which preceded and stimulated Dickens' Christmas Carols and Thackeray's Holiday Tales. 3

- Horace Binney Wallace, of rhiladelphia, said in his severe criticism upon lrving, that his works furnished the original and model of Dickens' descriptive manner, and mentions the "English Stage-Coachman" in the Christmas series as the preliminary study of the elder Weller. But is not the same series also the prelude of the great Christmas revival which came in with the Christmas Carol and all of Dickens' and Thackeray's Christmas books? Certainly Irving in a sense introduced Christmas to us. That is, he recalled and vividly reproduced the spirit of heartiness, of universal hilarity and hospitality and good feeling which are traditionally associated with the old, old, good old Christmas to which he appeals.4

1 Henry Seidel Canby, The Short Story in English (New York: Henry Holt \& Company, 1909), pp. 2I7, 267. Miss Mitford's "A Christmas Party," in Our Village, introduces the elements of a barrel of oysters and a wedding, which Later appear in Pickwick; the party resembles more nearly the poor folks' festivities of the Carol. Mitford, op. c1t., pp. 161-64.

2 Wilkins, op. cit., pp. 308-09.

3 curtis, op. cit., p. 281.

4 "Editor's Easy Chair," Harper's Magazine, 52 (January, 1876), p. 290. A similar linking of the names is found in a later" "Chair": 60 (January, 1880), p. 302 . 
Irving and Dickens: A Comparison. In addition to this external evidence, there is intermal evidence of a connection between the two writers, which is stronger. The long list of resemblances, both of plot and of phrase, between the Christmas chapters in the Sketch Book (1819-20), and those in Plckwlck Papers (1837), and a smaller number of resemblances found in other works, is too formidable to be pure coincidence. It is, therefore, given here in some detail.

1. The hero begins a journey in a stagecoach just bofore Christmas. ${ }^{1}$

2. The author pauses to moralize on Christmas, especially on the themes of family reunion and benevolence:

It is gratifying to see that home feeling completely aroused which holds so powerful a place in every English bosom. The preparations making on every side for the social board that is again to unite friends and kindred - all these have the most pleasing effect in producing fond associations and kindling benevolent sympathies. - - It is indeed, the seas on of regenerated feeing-the season for kindiing. . . the genlal flame of charity in the heart.2

Christmas was close at hand in all his bluff and hearty honesty; it was the seas on of hospitality, merriment, and open-heartedness. .

1 Irving, Sketch Book, p. 24l; Charles Dickens, The Plckwick Papers (New York: Thomas $Y$. Crowell \& Co., n. d.), I, 415 .

2 Sketch Book, pp. 237-39. 
- How many families whose members have been dispersed and scattered, far and wide, in the restless struggles of life, are then rounited . . How many recollections, and how many dormant sympathies, does Christmas-time awaken !

3. The author then indulges in a little conventional self-pity:

- . The 1dea of home, fraught with the fragrance of home-dwelling joys, reanimated the drooping spirit . Stranger and sojourner as $I$ am in the land--though for me no social hearth may blaze... --yet I feel the influence of the season beaming into my soul from the happy looks of those about me.2

We write these words now, many miles distant from the spot at which, year after jear, we met on that day, a merry and joyous circle. Many of the hearts that throbbed so gayly then, have ceased to beat. . Happy, happy Christmas, that can win us back to the delusions of our childish days. 3

4. The stagecoach in both cases is loaded with gifts

of assorted meats:

[The stagecoach] was loaded also with hampers of gamo, and baskets and boxes of delicacies; and hares hung dangling their long ears about the coachman's box presents from distant friends for the impending feast.4

Mr. Weller and the guard are endeavoring to insinuate into the fore-boot a huge codfish several sizes too large for it: . . Which has been left to the last, in order that he may repose in safety on the half-dozen

1 P1 ckw1ck, I, 415 .

2 Sketch Book, 239.

3 Pickwick, I, 415-16.

4 Sketch Book, 241 . 
barrels of real native oysters, al] the property of Mr. Plckw1ck [as a gift for his host].]

5. The villagers watch as the coach passes.2

6. Packages are delivered along the route.3

7. The weather is extremely cold. 4

8. On arriving, the hero finds a large number of guests, mostly relatives of the host, already assembled. 5

9. A "round card game" forms part of the evening's entertainment. 6

10. In each house, part of the entertainment is carried on in a large room, panels gleaming in the light of an unusual number of candles, hung with holly and evergreen.7 11. Mince pie forms an important part of the menu. 8 12. The gentlemen take a long walk after breakfast. 9 13. Part of the music is supplied by a harper, the

1 P1ckw1 ck, I, 416.

2 Sketch Book, 244; Pickwick, I, 418.

3 Ibid.

4 Sketch Book, 249; P1ckwick, I, 419.

5 Sketch Book, 254; P1ckwick, I, 422.

6 Sketch Book, 254; Plckwick, I, 425.

7 Sketch Book, 256-57; Pickwick, I, 430 .

8 Sketch Book, 257; Plckwick, I, 427.

9 Sketch Book, 266-67; P1ckwick, I, 430. 
only one in the neighborhood.1

14. An informal ball is held for the guests.2

15. Old Christmas games are kept up in the kitchen:

[In] the servants' hall . . a great deal of revelry was permitted, and even encouraged, by the squire, throughout the twelve days of Christmas, provided everything was done conformably to ancient usage. 3

"And so your family has games in the kitchen to-night, my dear, has they?" inquired Sam of Emma.

"Yes, Mr. Weller," replied Emma; "we always have on Christmas eve. Master wouldn't neglect to keep it up, on any account."

"Your master's a wery pretty notion of keepin' anythin' up, my dear," said Mr. Weller. "I never see such a sensible sort of man as he is, or such a reg'lar gen'lmin."

The ali: repaired to the iarge kitchen, in

which the family were by this time assembled, according to annual custom on Christmas eve, observed by old Wardle's forefathers from time immemorial.4

Among the games common to both households are: blind man's buff, 5 snap dragon, 6 and the suspended mistletoe.7

1 Sketch Book, 259; Pickwick, I, 430.

2 Sketch Book, 259-60; Pickwick, I, 430-32.

3 Sketch Book, 253.

4

Pickarick, I, 432-33, 434.

5 Sketch Book, 253, 292-93; Pickwick, I, 435-36.

6 Sketch Book, 253, Pickwick, I, 436.

7 Sketch Book, 254; Pickwick, I, 434-35. 
16. Whe host surveys his guests with pleasure:

The worthy squire contemplated these fantastic sports . . with the simple relish of childish delight. He stood chuckling and rubbing his hands. 1

Wardle stood with his back to the fire, surveying the whole scene with the utmost satisfaction.2

17. A huge wassa1l bowl, with roasted apples bobbing about, is passed around the circle. 3

18. A Christmas song is sung by one of the gentlemen. Irving's is apparently a genuine old song; Dickens wrote his own, but it is in the same spirit and in the same metre:

Now Christmas is come, Let us beat up the drum, And call all our neighbor's together, And when they appear Let us make them such cheer, As will keep out the wind and the weather. 4

We $i l i$ usher him in with a merry din That shall gladden his joyous heart, And we'll keep him up, while there's bite or sup, And in fellowship good, we'll part. . 5

19. Irving discourses at length about the heightening of the enjoyment of the social hearth, by the inclement weather without. Dickens puts one identical phrase into the
1 sketch Book, 297.
2 Pickwick, I, 434.
3 Sketch Book, 287-89; P1 ckw1ck, I, 436 .
4 Sketch Book, 259.
5 P1ckwick, I, 437. 
mouth of Mr. Wardle, as he looks about his jolly family circle, snugly gathered in.

. - and as the hollow blast of wintry wind . . rumbles down the chimney, what can be more grateful than that feeling of sober and sheltered security, with which we look round upon the comfortable chamber and the scene of domestic hilarity? ${ }^{1}$

"There's a snowdrift, and a wind that's piercing cold. I should know that, by the way it rumbles in the chimney."2

20. Goblin and ghost stories are told, all, of course, tmue, and backed up by much hearsay evidence. 3 Dickens' story of Gabriel Grubb deserves special consideration.4 21. Finally, each author winds up a chapter with an apology for his loquacity:

But enough of Christmas and its gambols; it is time for me to pause in this garrulity. 5

But bless our editorial heart, what a long chapter we have been betrayed into! We had quite forgotten all such petty restrictions as chapters, we solemnly declare. 6

Even the outstanding contrasts in the two sets of sketches are those of differences between the two writers:

\footnotetext{
1 Sketch Book, 236.

2 Plckwick, I, 438.

3 Sketch Book, 293-95; Pickwick, I, 438, II, 1-12.

4 cf. post, pp. 17-19.

5 Sketch Book, 298.

6 Plckwick, I, 438.
} 
1. Irving, who thought Dickens frightfully crude, I selects a higher stratum of society about which to write.

2. The Bracebridge wassail bowl, appropriately, is filled with mixed wines; that at Dingley Dell, with ale.2

3. Squire Bracebridge encourages games in the kitchen; Mr. Wardle and his guests join in the kitchen frolic. 3

4. Geofrey Crayon is an interested but detached onlooker; Mr. Plckwick and Sam Weller are the life of the party. 4

It is evident that Gabriel Grubb is the ancestor of Ebenezer Scrooge. The evidence is not conclusive, but it is interesting, that he bears certain resemblances to Irving's most famous character, 5 and that certain other points in his story seem like Sketch Book echoes.

1 williams, op. cit., II, 117.

2 Sketch Book, 287; Pickwick, I, 436.

3 Sketch Book, 253; Pickwick, I, 434-38.

4 Sketch Book, 263-64; 279, 292; P1ckwick, I, 426, $428,431-32,435$.

5 one of $D_{1}$ ckens' blographers comments: "The influence of Washington lrving, so conspicuous in $D_{\text {lckens }}$ ' earlior work, is in [P1ckwick] scarcoly noticeable. Apparently, however, Mr. Winkle owed his name to the more famous sportsman Rip Van Winkle; and Gabriel Grub [sic], with his fondness for Hollands and his reappearance after ten years, seems to be the same old friend slightly disguised." Thomas Wright, The Iife of Charles Dickens (New York: Charles Scribner's Sons, 1936), p. 97. 
In the first place, the text of Dickens' little story might have been taken from a paragraph by Irving:

He who can turn churlishly away from contemplating the felicity of his fellow beings, and can sit down darkling and repining in his loneliness when all around is joyful, may have his moments of strong excitement and selfish gratification, but he wants the genial and social sympathies which constitute the charm of a merry Christmas. 1

"Oh, yes,..." replied the goblin; "we know the man . . Who struck the boy in the envious malice of his heart, because the boy could be merry and he could not."

This story has at least one moral, if $1 t$ teach no better one--and that is, that if a man turn sulky and drink by himself at Christmas time he may make up his mind to be not a bit the better for it. 2

It may be a series of coincidences, but Gabriel Grubb, like Rip $V_{a n}$ winkle, is accosted first by one fantastically aressed dwarf, 3 then by a group of them. 4 They know his name. 5 One of the dwarfs wears a sugar-loaf hat. 6

I Sketch Book, 239.

2 Pickwick, II, 6, 12. Both this comment, and that of Irving, above, may be echoed also in the concluding paragraph of the Carol: "He had no further intercourse with Spirits, but 11ved up on the l'otal Abstinence Principle, ever afterwards; and it was always said of him, that he knew how to keep Christmas well, if any man alive possessed the knowledge." Carol, p. 98 .

3 Sketch Book, 50; Pickwick, II, 4.

4 Sketch Book, 51; Pickwick, II, 6.

5 Sketch Book, 50; Pickwick, II, 4-5.

6 Sketch Book, 50; Pickwick, II, 4. 
He indulges in a bottle of Hollands; ${ }^{I}$ and he awakens from his magic sleep with a crick in his back.2 on returning to his village, after years' absence, he is recelved with suspicion and incredulity. 3

Furthermore, one of the pictures which the goblins showed the sexton was that of a tenderly-reared woman meeting adversity with courage and grace.4 This is the plot of one of the most popular of Irving's sketches, "The Wife." 5

Such a series of resemblances between Dickens' early Christmas efforts, and the work of an author whom he admired, cannot be entirely coincidence. It would be interesting if America's Christmas fiction, deriving so much as it undoubtedly does from Dickens, should have also a remoter ancestry which, in turn, is American.

1 Sketch Book, 52; Pickwick, II, 4.

2 Sketch Book, 53; P1ckwick, II, 10.

3 Sketch Book, 55-60; Pickwick, II, 11.

4 P1 ckw1 ck, II, 10.

5 Sketch Book, 31-40. 
GHAPTER II

CHARLES DICKENS: A CHRISTHAS CAROL 


\section{CHAPTER II}

\section{CHARLES DICKENS: A CHRISTMAS CAROI}

The publication, in 1843, of A Christmas Carol, by Charles Dickens, is probably the outstanding landmark for any study of Christmas in English and American literature. In the present study it will be considered not in itself, but in relation to its background, and to its later influence.

The Carol: Its Background. The writing of a Christmas story, as has been seen, I was not without precedent in Dickens' own experience. Even before Pickwick, we find, among the Sketches by Boz--the first of which was published in January, 1834, and which were published in two volumes in 1836--one entitled "A Christmas Dinner," in which are contained "the germs of half a dozen tales and chapters... the whole of the Carol philosophy is tersely put in the heterodox concluding sentence." 2 The sentence referred to is as follows:

And thus the evening passes, in a strain of rational good wIIl and cheerfulness, doing more to awaken the

\footnotetext{
1 cf. ante, pp. 1l-19.

2 Charles Dickens, Sketches by Boz (New York: Charles Scribner's Sons, 1902), p. $\frac{1}{1 x}$
} 
sympathies of every member of the party in behalf of his neighbor and to perpetuate their good feeling during the ensuing year, than half the homllies that have ever been written, by half the Divines that have ever lived.I

This conclusion anticipates the very comments made by Lord Jeffrey and others on the publication of the Carol?

In the Christmas chapters of Pickwick, Dickens further developed his own form of the Christmas story. of special importance is Mr. Wardle's tale, "The Story of the Goblins who Stole a Sexton,"3 since Gabriel Grubb, the misanthrope, hater of Christmas, is the immediate ancestor of Ebenezer Scrooge.

The relation of the Christmas chapters in Plckwlok to those in Irving's Sketch Book has already been noted. A fow paragraphs appear in the Carol which seem to be Sketch Bools echoes also.

1. Game, poultry, and other luxuries of the table, were in brisk circulation in the villages; the grocers', butchers' and fruiterers' shops were thronged with customers . " "The country maid leaves half her market, and must be sent again." 4

The poulterers' shops were still half open, and the fruiterers' were radiant in their glory. . 'the Grocers'! oh, the Grocers'! nearly closed, with perhaps

1 Dickens, op. cit., I, 262.

2 John Forster, The Life of Charles Dickens (New York: Charles Scribner's Sons, 1902), I, 345 .

3 cf. ante, $\mathrm{pp}$. 17-19.

4 Washington Irving, The Sketch Book of Geoffrey

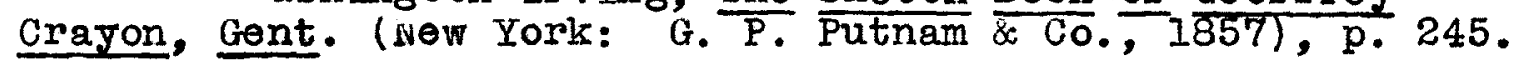


two shutters down or one; but through those gaps such glimpses !. . the customers were all so hurried and so eager in the hopeful promise of the day, that they tumbled up against each other at the door . . . and left their purchases upon the counter, and came running back to fetch them, and committed hundreds of the like mistakes in the best humor possible.1

2. One fine blue-ejed girl of about thirteen, with her flaxen hair all in beautiful confusion, her frolic face in a glow . . Was the chief tormenter; and from the sIyness with which Master simon avoided the smaller game, and hemmed this wild ilttle nymph into corners, and obliged her to jump shrieking over chairs, I suspected the rogue of being not a whit more blinded than was convenient.2

And I no more believe l'opper was realiy blind than I believe he had eyes in his boots. My opinion is, that 1t was a done thing between him and Scrooge's nephow... I'he way he went after that plump sister in the lace tucker was an outrage on the credulity of human nature. Knocking down the fire-irons, tumbling over the chairs, -. wherever she went, there went he.3

Such points of resemblance, though striking, are not plentiful. Dickens, it would seem, had by that time got into his own stride, and had less need of a model.

So much for Dickens' apprenticeship in Christmas literature. As to the factors in his own life which may have helped precipitate the writing of the Carol, his biographer, Forster, gives us this account: About october 6, 1843, Dickens had visited Manchester, to take part in the dedication

1 Charles Dickens, A Christmas Carol, in Christmas Books (London: Chapman \& HaII, Ld., n. d.), pp. 53-54.

2 Irving, Sketch Book, pp. 292-93.

3 Dickens, Carol, p. 68. 
of some philanthropic institution. "Here he spoke mainly on a matter always nearest to his heart, the education of the very poor." 1 He did not begin work on the story

. . until a week after his return from Manchester, where the fancy first occurred to him, and before the end of Novgmber he had finished his memorable Christmas Carol.

A less kindly biographer attempts to psychoanalyze

the author thus:

The hysterical state in which Dickens wrote his Carol was due to his internal conflict over his quarrel with [his publishers], for which he tried to find relief not by behaving reasonably, but by making believe that his greed and self-protective egotism had been magically dispersed without any effort of his own will. 3

The Carol: Its Influence. The Christmas sketch of Irving, acquiring in Pickwick more and more of the aspects of pure fiction, at last in the Carol had become the Christmas tale.

But it had become more than a tale. It had become also the Christmas sermon, with a strong social message.

In writing his Christmas books, Dickens had two aims in view. One was his own pleasure. . His other aim was to remind the rich and the well-to-do that Christmas is not only a day of stuffed turkeys and plum-pudaings, but a day of reconciliation and kindness, which cannot

1 Forster, op. cit., I, 323.

2 오. cit., I, 325.

3 Hugh Kingsmill [Lunn], The Sentimental Journey; A Life of Charles Dickens (New York: William Morrow \& Co., 1935), p. 133. 
be worthily celebrated unless one has made one's peace with the poor. I

- These books, which Thackeray called a national benofit, are the most direct emotional appeal of Dickens for sympathy with the poor.2

It had become also the story of the common people. And since, as Abraham Lincoln is reported to have observed, there are so many of those, there was inevitably created an enormous demand.

For more than a decade the Annual and the Gift Book had been flourishing, on both sides of the Atlantic. 3 Some titles literaliy began with the word "Christmas." The subtitle of nearly all was "A Christmas, New Year's and Birthday Present." E. Douglas Branch makes an interesting suggestion in connecting the thought of the popularity of these books, with that of the simultaneous popularity of the books, especially the Christmas stories, of Dickens: "Coincidentally gift-books and 'embellished' annuals throve, the literary

1 Andre' Maurois, Dickens, Hamish Motes, translator (New York: Harper and Brothers, 1935), p. 61.

2 John Macy, "Charles Dickens, Household Word," The Bookman, 68 (December, 1928), p. 426.

3 Frederick W. Faxon, Literary Annuals and Gift Books (Boston: Boston Book Company, 1912). Kalph Thompson, American Literary Annuals and Gift Books, 1825-1865 (New York:

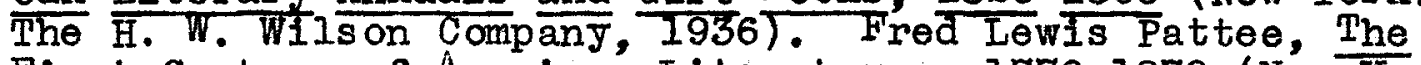
First Century of American Iiterature: 1770-1870 (New York: D. App Ieton-Century Co., Inc., 1934), Chap. 24. 
specials for the rising tide of holiday trade." Closely akin to Annuals are "Christmas numbers." Stephen Leacock suggests a connection of these with the rise of the Christmas story, encouraged by the Carol popularity:

At the close of that year (1843) Dickens opened up a new line of writing, on which henceforth rested a large part of his work, and a large part of the affection which his work inspired. This was his famous Christmas Carol, the first of the long series of his Christmas books, and of the special Christmas numbers of his later magazines. Dickens did not invent "Christmas stories" and "Christmas magazines," but he went a long way towards giving them the place in English and Americen Iife that they have ever since enjoyed.?

It was the story of the common people which came to America. Branch relates its effect on American life and literature:

Our social Christmas awaited the rise of the middle class, when effluvia from the family-cult, humanitarian impulses, and business principles were to unite in fragrance as Christmassy as the pungent odor of balsam fir. - Dickens more than anyone helped to transplant the possibility of that social sweetness.

In 1843 , between the covers of American imprints as well as British, the happy Cratchits were rejoicing over "such a goose!" . . and [the characters] of Dickens' Chrlstmas pieces became in a sense naturalized items of our literature. 3

1 E. Douglas Branch, "Jingle Bells: Notes on Christmas in Amerlcan Iiterature," Saturday Review of Literature,
17 (December 4, 1937), p. 3.

2 Stephen Leacock, The Greatest Prges of Charles Dickens (Doubleday Doran \& Company, Inc., I934), $\frac{\mathrm{p}}{112 .}$

3 Branch, 1oc. c1t. 
Or, as Pattee puts it, more unkindly:

- "America was teaching the people--the "mass," the imob,"--to read, and here was something they could read. -. Doubtless to him, more than to any other source, may be traced the sickiy-sweet sentimentality that so flooded the prose and poetry of America during the forties and fifties. 1

This sentimentality was by no means confined to Christmas stories, either of Dickens or of any other writer, but it is certainly characteristic of many, perhaps of most.

As a sample of the influence of the Carol on the Christmas stories written in the United States, one need only observe some sentences from the first Christmas story to appear in The Atlantic Monthly. ${ }^{2}$ The story is not of first rank. It has, however, a freshness and earnestness which go far to counterbalance the sentimentality. While It attempts a social message, the latter part of the story is concerned entirely with the themes of forgiveness and reconclilation, occurring, very properly, at Christmas time. The lame mulatto girl, Lois, who serves as a symbol of childlike simplicity, appears to have as antecedents a whole line of Dickens' more pathetic juveniles. The following quotations seem to be Carol echoes:

1 Pattee, op. cit., p. 445.

2 "A Story of Today," The Atlantic Monthly, 8 (october, November, December, 1861) 47 1-86, 582-97, 701-18; 9 (January, February, March, 1862) 40-51, 202-13, $282-98$. 
There was not a homely pleasure of those years gone - . that he did not recail and linger over with a boyish yearning, now that these things were gone forever. 1

He could see the signs of its [Christmas'] coming even in the shop-windows glittering with miniature toys, in the market-carts with their red-faced drivers and heaps of ducks and turkeys, in every stage-coach or omnibus that went by crowded with boys home for the holidays. 2

The very trade today had a jolly Christmas face on; the surly old banks and pawn-brokers' shops had grown ashamed of the $1 \mathrm{r}$ doings and shut their doors and covered their windows with frosty trees and cathedrals and castles; the shops opened their inmost hearts; some child's angel had touched them, and they flushed out into a magic splendor of Christmas trees, and lights, and toys; Santa claus might have made his headquarters in any one of them. 3

As for the dinner, it was the essence of all Christmas dinners: Dickens himself, the priest of the genial day, would have been contented.4 that. 5

The dinner, perhaps, was fresher and heartier after

It is never possible wholly to separate Dickens' relation to the Iiterature of Christmas from his relation to the observance of Christmas. The close connection, in the popular mind, of Dickens and Christmas, is expressed in an incldent recalled by Maurois:

$$
\begin{aligned}
& 1 \text { "A Story of Today," 9 (February, 1862), } 208 . \\
& 2 \text { op. cit., pp. } 209-10 . \\
& 3 \text { op. cit., p. } 211 \\
& 4 \text { op. cit., } 9 \text { (March, 1862), p. } 293 . \\
& 5 \text { Ibid. }
\end{aligned}
$$


When Dickens died in 1870 ... a story is told of one small boy who asked: "Is Mr. Dickens dead? And will Father Christmas die too?"I

Macy terms the Christmas books, "a creation so peculiarly the spiritual property of Dickens that he seoms to have... an international copyright on the holiday. 2

Irving's account of the Christmas festivities at Bracebridge Hall gives pleasure; but it has an air of detachment, and a flavor almost antiquarian. There is nothing detached in our relation to 0ld Scrooge and to Tiny Tim. Thus Dickens had an effect on literature and life of which Irving was incapable.

The revival of the observation of Christmas is largeIy due to Washington Irving and Charles Dickens. The honour may be fairly divided between them. Bracebridge Hal1 [sic] came first, and was no doubt the prototype of the scenes at Dingley Dell, but Dickens' work had a far greater vogue than Irving's, and $h$ is influence was no doubt greater too.3

It was the story-sermion of the common people--with its accurate blending of the sensate and the ldeational, its exact balance of warmth and cold--which became the Christmas classic, and which established an institution in English and American Iife.

1 Maurois, op. cit., p. 3.

2 Macy, op. cit., p. 426.

3 Wright, op. cit., p. 169. 
CHAPTER III

NATHAN IEL HAWTHORNE 
In starting contrast to the Carol, and, indeed, to practically all Christmas stories of the nineteonth century, is "The Christmas Banquet," by Nathaniel Hawthorne, 1 pubIished in 1846.

Not only is this story utteriy different in spirit from those of Dickens, but in actual Iife Hawthorne's reactions to the English Christmas were the reverse not only of Dickens', but of Irving's as well. And yet, certain stories of Hawthorne and Dickens present such surprising superficial parallels that they suggest the possibility of a connection.

"The Christmas Banquet." This story reverses, as in a photographic negative, the relation of warmth and cold customary in Christmas stories, with their December wind and snow used merely as a foll far the warmth of the fire on the hearth and the warmth of spirit of those gathered about the hearth. Dickens had, to be sure, heightened the pathos of the deaths of Iittle Nell and of Tiny Tim by hanging Christmas holly about their beds; but tears are, after all,

1 Nathanlel Hawthorne, "The Christmas Banquet," in Mosses from an Old Manse (Boston: Houghton Mifflin Company, 1882), $\mathrm{pp} .3 \overline{22}-\overline{46}$. 
Iukewarm. "The Christmas Banquet" has at its center the cold heart of Gervayse Hastings, and briefly cites the traditional cheer of Christmas merely as ironic contrast. Hawthorne, through his fictitious narrator, sets forth in a preface the aim of the allegory: "To sieze hold of a personage who glides past me occasionally... the demands that spirit makes upon spirit are precisely those to which he cannot respond."I

The account of the melancholy testator's founding of the annual banquet sets the key for the story: - A certain old gentleman . . devised a considerable sum for establishing a fund, the interest of which was to be expended, annually forever, in preparing a Chris tmas banquet for ten of the most miserable persons that could be found. It seemed not to be the testator's purpose to make these half a score of sad hearts merry, but to provide that the stern or fierce expression of human discontent should not be drowned, even for that one holy and joyful day, amid the acclamations of festal gratitude which all Christendom sends up. And he desired, likewise, to perpetuate his own remonstrance against the earthly course of Providence, and his sad and sour dissent from those systems of religion or philosophy which either find sunshine in the world or seek to draw it down from heaven.2

Among the guests appears ciervayse Hastings, a young man so apparently favored, whose Iife is so free from sorrow, sin, or other blight, that his presence, year after Jear, is a cause of speculation and resentment on the part

\footnotetext{
1 "Christmas Banquet," p. 322.

2 op. c1t., p. 323.
} 
of the other guests, all able to establish contacts with one another, but never with Hastings nor he with them:

-. Throughout the feast it was remarked that .. Gervayse Hastings was unsuccessful in his attempts to catch the pervading spirit. At any deep, strong thought - . he looked mystified and bewildered. .

"Sir," said the misanthropist bluntly," . . . my companions and myself must seem no more than the shadows flickering on the wall." I

Finally, at Hastings' last banquet, the aged man reveals the source of his unsuspected woe; That he is incapable of human feelings and of human contact. As Arvin puts it, "the most unhappy wretch is the man who... . can neither share nor understand the ordinary emotions of mankind." 2

Hawthorne had possibly contemplated since college days the theme of a yearly banquet with the guests growing steadily more feeble. 3 The real germ of the story had found definite shape when on october 25,1835 , he made this entry in his journal:

A Thanksgiving dinner. All the miserable on earth are to be invited.. The giver of the feast goes out

I "Christmas Banquet," p. 331.

2 Newton Arvin, Hawthorne (Boston: Little, Brown and Company, 1929), p. 136

3 Louise Hastings, "An Origin for 'Dr. Heidegger's Experiment, " American Iiterature 9 (January, 1938), 403-10. 
to deliver his invitations. Some of the guests he meets In the streets, some he knocks for at the doors of their houses... Who must be the giver of the feast...? A man who has never found out what he is fit for... He should meet some pious, old, sorrovful person, with more outward calamities than any other, and invite him, with a reflection that piety would make all that miserable company truly thankful. I

It is interesting to note the transition from the Thanksglving dinner of the notebook jotting, to the Christmas banquet of the completed story. Two explanations suggest themselves:

In the first place, Uhristmas, with its universal associations of good cheer, forms a more nearly diametric contrast to the sardonic purposes of the testator than would Thanksgiving, with its Puritan heritage. ${ }^{2}$

In the second place, the decade between notebook entry and publication had witnessed a literary phenomenon: The appearance of the christmas books of charles Dickens and their immediate establishment as an institution in English and American life. 3 Hawthorne may simply have been

1 Nathaniel Hawthorne, The Heart of Hawthorne's Journals, Newt on Arvin, editor (Boston: Houghton Mifilin Company, 1929), pp. 9-10.

2 "We have a touch in the Americanized Christmas story of the moralistic quality of the American Thanksgiving story. This was seldom written, at first, for the mere entertainment of the reader. . . It was meant to edify him." "Editor's Study," Harper's Magazine, 80 (December, 1889), p. 158.

3

Cf. ante, Chap.II 
following a popular trend.

Hawthorne and Dickens: Parallel and Contrast. If it be true that Hawthorne was influenced by the Dickens vogue in the choice of materials for "The Christmas Banquet," it is not the only instance in which a connection can be seen. They present also certain parallels, which, though too slight to form the basis for any claim that one writer might have influenced the other, are nevertheless sufficiently striking to warrant attention.

Hawthorne and Dickens never met. Although the former wrote in his journal on July 10, 1856, "I must see him before I finally leave England,"I nevertheless, "during the jears he Ilved in England, Hawthorne - . failed to take advantage of the opportunity to meet the prime literary figures of his day." 2

Hawthorne's reaction to English Christmas differs strongly from that of native-born Dickens, and of cosmopolitan Irving. In 1854 he was able to write from England:

I think I have been happier this Christmas than ever before,--by my own fireside, and with my wife and chil-. dren about me, more content to enjoy what I have,--less

\section{Journals, p. 223.}

2 Herbert Gorman, Hawthorne, a Study in Solitude (New York: George H. Doran Company, 1927T, $\frac{1}{\mathrm{pp} \cdot 117-18 . ~}$ 
anxious for anything beyond it in this life. 1

But by Christmas 1855, with Mrs. Hawthorne and the two Iittle girls in Spain for the winter months, 2 Hawthorne in his Liverpool boarding house was in no mood to enjoy the Christmas celebration. Annoyed by the boldness of the housemaids in pulling the boarders under the mistletoe, he noted in wry satisfaction, "I doubt whether any gentleman but myself escaped."3 In reporting the market scenes he noted with some disgust details which would have delighted Dickens: "The market houses, at this season, show the national taste for heavy feeding." 4 The garlanded carcasses were particularly offensive. His real trouble appears in the concluding sentence of the entry: "I can never forget the distinction between English and American." 5

Those fatted pigs haunt his journal for the next two Christmases. The carolers sing "wretched doggerel rhymes." 6

1 Nathaniel Hawthorne, English Note Books in Complete Works, (Boston: Houghton, Miffilin and Company, 1898), VII, 549 .

2 Gorman, op. cit., p. 119.

3 English Note Books, VIII, 177.

4 op. cit., VII, 178.

5 Ibid.

6 op. cit., VIII, 386. 
Shops and Christmas trees are decorated with "gaudy fruit."I "We think of going to the Crystal Palace to spend the festival day . - but, do what we may, we shall have no home feeling or fireside enjoyment."2 In short, though Hawthorne referred to England as "Our 0ld Home," he was never quite at home there.

Although the two men never met in person, Dickens seems to have enjoyed Hawthorne's stories. Forster, telling of a letter fram Dickens in 1851 which expressed disappointment in The Scarlet Letter, adds:

In Mr. Hawthorne's earlier books he had taken especial pleasure; his Mosses from an 0ld Manse having been the first book he placed in my hands on his return from America, with reiterated injunctions to read it. 3

Since Forster here seems to be referring to Dickens' first return, in June, 1842, Mosses from an old Manse, published in 1846, obviously was not the book brought back. However, It is not unreasonable to suppose that Dickens may have brought a copy of Twice-Told Tales, printed first in 1837, and in revised and enlarged edition early enough in 1842 for

1 English Note Books, VIII, 598.

2 Ibia.

3 Forster, op. cit., II, 72 . 
a review to appear in the April magazines. 1

Twice-Told Tales contains one story, "Fancy's Show Box,"2 not a Christmas story, which forms an interest parallel and contrast with the Carol (1843) and with its Pickwick predecessor, "The Story of the Goblins Who Stole a Sexton."3 In each of the three stories the main character is visited by supernatural beings who show him pictures of life, thereby effecting a change in his entire nature and outlook. While the sexton, Gabriel Grubb, of Dickens' earlier story, is shown glimpses into the lives of others, the later Ebenezer Scrooge, like Mr. Smith of "Fancy's Show Box," is shown also scenes from his own past. While Gabriel and Scrooge are stirred to a healthy "repentence unto life," the effect on $\mathrm{Mr}$. Smith is that of a devastating remorse.

It may or may not be significant that, just as the publication of "Fancy's Show Box" brlefly preceded that of the Carol, so the appearance of "The Christmas Banquet" was

1 Edgar Allan Poe, review of Twice-Told Tales, Graham's Magazine, April, 1842, in complete Works of' Edgar Allan Poe, edited by James A. Harrison. (New York: Thomas Y. CrowOII and Company, 1902) XI, 102-4.

2 Nathaniel Hawthorne, "Fancy's Show Box," in Twice Told Tales (Boston: Houghton Mifflin Company, 1882), pp 250-5\%. 
followed by two Christmas tales by Dickensl which treat of the endowment of a charity for a specified number of beneficiaries. The contrast lies in the fact that in both instances the purpose of the testator is sympathetic, even genial:

$$
\begin{aligned}
& \text { Richard Watts, Esq. } \\
& \text { by his will dated } 22 \text { Aug. } 1579 \\
& \text { founded this charity } \\
& \text { for Six poor Travellers . . . }
\end{aligned}
$$

It was in the ancient little city of Rochester in Kent, of all the good days in the year upon a Christmas-eve, that I stood reading this inscription over the quiet door.2

"It was quite a pleasure to know that one of our founders. . . left in his will, among the other bequests he made us, so much to buy holly, for garnishing the walls and windows, come Christmas. 'Ihere was something homely and friendly in it. . We took a liking for his very picter that hangs in what used to be, before our ten poor gentlemen commuted for annual stipend in money, our great Dinner Hall.-- ... a scroll below him,. . Lordl keep my memory green!"3

Part of the story, The Haunted Man, "dimly conceived" in 1846, begun in 1847, and completed in the autumn of

I Charles Dickens, The Haunted Man and the Ghost's Bargain, in Christmas Books (London: Chapman \& Hall, Ld., n. d.), pp. 411-525. CharIes Dickens, "The Seven Poor Traveliers," [1854] in Christmas Stories (n. p., n. d.), pp. 79-91.
2 Charles Dickens, "Seven Poor Travellers," p. 81.
3 Charles Dickens, The Haunted Man, p. 430 . 
1848, I does bear same resemblance to "The Christmas Banquet" Its hero, Redlaw, attempts forgetfulness of sorrow, and in so dolng cuts himself off from humanity almost as absolutely as does Gervayse Hastings:

"I have lost my memory of sorrow, wrong and trouble - . and with that I have lost all man would remember!"2 His redemption resembles that of the hero of the "Banquet's" companion-piece, "The Bosom Serpent": 3 in each case the evil spirit is exorcised through an act of self-forgetfulness, and through a good woman's example. Under Hawthorne's management, Gervayse Hastings seems almost credible, and dominates the story throughout. Dickens seems to have been a little self-conscious in his handling of Redlaw, and to have turned in relief--shared by the reader--to the lusty Tetterbys. In the Introduction to Christmas Books, Andrew Lang observes: "The idea of The Haunted Man might have occurred to Hawthorne, but even he could scarcely have made it plausible."4

1 Andrew Lang, Introduction to Christmas Books, p. xil. See also Frederic George Kitton, Charles Dickens: His Life, Writings and Personality (London: T. C. \& E. C. Jack, $\frac{1906}{\text { ) }}$, p. 171 .

2 Haunted Man, p. 516.

3 Nathaniel Hawthorne, "The Bos om Serpent," in Mosses from an old Manse, pp. 30i-2l.

4 Christmas Books, p. xil. 
Where Irving was irresistibly draw to the English celebration of Christmas, Hawthorne was only repelled. Where Dickens has endowments established for the purpose of increasing cheer, Hawthorne's founder desires to heighten misery. Where Dickens permits visions of Iife to have a positive influence, those described by Hawthorne are negative in effect.

Thus, just as Irving may be said to have fathered the simple Christmas sketch with its emphasis on sensate detail; just as Dickens produced the Christmas classic through a balance of sensate and ideational, story and sermon; so Hawthorne, in his one Christmas effort, passes on to a treatment which is at once entirely ideational--and entirely pessimistic.

Ironic in spirit, using Christmas warmth as a foil for spiritual coldness--though not denying nor disparaging that warmth--, and using the symbols of Christmas for purposes of allegory, "The Christmas Banquet" ran counter to the nineteenth century Christmas tradition. Its like is not noticeable again in American Christmas literature for another alxty jears, when its spirit reappears in the attempted Christmas Trilogy of a spiritual kinsman of Gervayse Hastings. 
CHAPTER IV

CHRTSTMAS IN THE AMERICAN SCENE 


\section{CHAP'IER IV}

\section{CHRISTMAS IN THE AMERICAN SCENE}

The picture of an American celebration of Christmas makes its appearance very early in American fiction. In 1823, James Fenimore Cooper, describing in The pioneers the Iife of 1793, introduced a number of Christmas customs into the first nineteen chapters. We watch the settlers awkwardly undergoing their first Church of England service in a bare loft decorated with evergreen; we attend a turkeyshoot; we hear of an expected visit from "Santaclaus"--whom Cooper feels obliged to identify in a footnote, so extensively has puritanism encroached on good old New York custom; and we note the rich delight of the Negro servants in the celebration.

The genuine American Christmas story, however, did not develop until a much later date. The Christmas story and the Christmas celebration were mutually influential. Adopted and naturalized in the United States as a consequence of the wide popularity of Dickens, they proceeded to acclimate themselves.

A study of the Christmas stories appearing in the three magazines, The Atlantic Monthly, Harper's Magazine, and Scribner's Magazine, supplemented by short-story collections of various authors, gives a fair cross-section of the 
Christmas story in the United States for the period from 1872 to World War I.

As though to demonstrate the universality of its appeal, the Christmas theme appears in the custom and color of many regions and groups.

After the Civil War, the Christmas story became an abundant commodity. Regional writers liked the theme, in part because it wouldn't offend anybody; it had "color;" it was a useful deus ex machina to bring peace at the denouement of a troubled story. I

A further explanation of the tendency to locate the Christmas story in the provinces, or in the lower economic brackets, may consist in congruity. In many of these tales the "color" is as thin as the plot; and yet, they create an impression of reality which is ordinarily absent from stories whose characters are, for example, New York club men. A plantation Christmas may bring an abundance of good things, but they are simple, unsophisticated things. ithe true meanIng of the day, it would appear, is among the things which are hid from the wise and prudent, and revealed unto babes. The Professor of James Lane Allen's The Bride of the Mistletoe nearly has his home wrecked as a consequence of erudite delving into Christmas lore; the rich man of Henry van Dyke's

1 E. Douglas Branch, "Jingle Bells: Notes on Christmas in American Literature." Saturday keview of Literature, 17 (December 4, 1937), p. 3 . 
The Mansion has no appreciation of Christmas until a vision brings him the lesson of humflity. The whole-hearted enjoyment of Christmas is reserved for folk such as these of the North Carolina foot hills:

There was a vague idea throughout the clarin' that the day was one in which to be friendly and to give old grudges the go-by: the Iord (with whom Aunt Dilly was better acquainted than the rest) was supposed, for some reason, to be nearer at hand on that day than usual, though not so near as to make anybody feel uncomfortable. 1

The Christmas Story Goes West. "The Christmas theme's most celebrated excursion into the West," writes Branch, "is, rightly enough, Bret Harte's 'How Santa Claus Came to Simpson's Bar." While he does not make clear in what this "rightness" consists, he might well have reference to Harte's acknowledged kinship with Dickens. As a biographer writes:

In $1846 \ldots$. the art of Dickens, with its mingling of humor, pathos, sentiment, and melodrama, bursting upon him at an impressionable age, became his ideal.3

Dickens himself recognized his own features in the younger writer. Forster tells us that, a few months before his

I Rebecca Harding Davis, "At the Station," Scribner's Magazine, 4 (December, 1888), p. 694.

2 Branch, op. c1t., p. 4

3 George Rippy Stewart, Jr., Bret Harte, Argonaut and Exile (Boston: Houghton Mifflin Company, 1931), p. 22 . 
death, Dickens had sent him

two sketches by a young American writer far away
in california. id in which he had found such subtle
strokes of character as he had not anywhere else in
late years discovered; the manner resembling himself,
the matter fresh to a degree that had surprised him;
the painting in all respects masterly; and the wild
rude thing painted, a quite wonderful reality. I have
rarely known him more moved.

Harte's reverence for Dickens is apparent in the tribute, "Dickens in Camp," written at the latter's death:

And as the firelight feli

He read aloud the book wherein the Master Had writ of Iittle NeII.2

Something of Dickens appears in "How Santa Claus Came to Simpson's Bar," even though the pathetic child of the story bears no resemblance to the angelic Tiny Tim. Harte has wisely given us an unkempt brat whose favorite recreation is throwing stones at Chinamen:

- . It was the voice of a small boy, its weak treble broken by that preternatural hoarseness which only vagabondage and the habit of premature self-assertion can give. It was the face of a small boy . . . that might have been pretty and even refined but that it was darkened by evil knowledge from within, and dirt and hard experience from without. 3

I John Forster, The Life of Charles Dickens (New York: Charles Scribne r's sons, 1902), I, 143 .

2 Bret Harte, "Dickens in Camp," in Poems (Boston: James R. Osgood and Company, 1871), p. 34.

3 Bret Harte, "How Santa Claus Came to Simpson's Bar," The Atlantic Monthly, 29 (March, 1872), p. 352. 
Th1s picture of Johnny appears to derive something from that of the wretched little beings whom the Ghost shows to Scrooge :

- . Where graceful youth should have filled their features out and touched them with its freshest tints, a stale and shrivelled hand like that of age, had pinched, and twisted them, and pulled them into shreds. Where angels might have sat enthroned, devils Iurked.1

Dick Bullen's epic ride after Christmas toys ends, for all

its frontier detail of bandits and high water, on the approved note of sentiment:

And even so, bedraggled, ragged, unshaven and unshorn, with one arm hanging helplessly at his side, Santa Claus came to Simpson's Bar and fell fainting on the first threshold. The Christmas dawn came slowly after, touching the remoter peaks with the rosy warmth of ineffable love. And it looked so tenderly on Simpson's Bar that the whole mountain, as if caught in a generous action, blushed to the skies.2

Thus came Christmas in the Westerm story.

Christmas in the Story of the South. Christmas came more simply in the South, if we are to believe Thomas Nelson Page. One sentence from "The Burial of the Guns," not a Christmas story, is significant: ". . the quiet old plantation, in which the harvest, the corn-shucking and

1 Charles Dickens, A Christmas Carol, in Christmas Books (Lond on: Chapman \& Hall, Ld., n. d.), p. 72 .

2 "How Santa Claus Came," p. 357. 
the Christmas holidays alone marked the passage of the seasons .. "I Similarly, in "The Old Dominion," Christmas is listed as one of three or four events in the life of the planter; 2 and in "Ole 'Stracted," it is used casually to indicate the passage of time. 3

Thus Christmas, to Page, is something that comes as naturaliy as the year turns; it is to be enfoyed simply and confidently. Though the characters in a number of his stories celebrate Christmas under difficulties, they are merely such difficulties as one may overcome by work, by ingenuity, or by living above them. Yankees, or landladies, or parishoners, or the weather may be cold and unfriendly, but not the universe.

Page's Christmas stories differ widely among themselves both in tone and in setting. "Charlie Whittler's Christmas Party,"4 an unsuccessful attempt at farce, occurs

I Thomas Nels on Page, "The Burial of the Cuns," in The Burial of the Guns (New York: Charles $S_{c r i b n e r ' s} S_{\text {ons, }}$ $1 8 9 4 \longdiv { , ~ p . ~ } 4 6$.

2 Thomas Nelson Page, "The Old Dominion," Haxper's Magazine, 88 (December, 1893), p. 16.

3 Thomas Nelson Page, "Ole 'Stracted," Harper's Magazine, 73 (October, 1886), p. 699.

4 Thomas Nelson Page, "Uharlie Whittler's Christmas Party," Harper's Magazine, 86 (December, 1892), pp. 73-84; also included in Pastime Stories (New York: Charles Scribner's Sons, 1894), pp. 73-84. 
In a New York lodging house. "Ihe Stable of the Inn,"I a story in the van Dyke manner, told with reticence and charm, has a Bethlehem setting. However, most of the stories have a Southern background, occurring before, during, or after the War. Polly, a Christmas Recollection ${ }^{2}$ is threadbare, with its fire-eating, julep-drinking Colonel. "Rachel's Lovers"3 is dull horseplay. Both of these are plantation stories, one in the big house, and one in the quarters. A Captured Santa Claus, 4 and The Shepherd Who Watched by Night, 5 while appealing, have a little too much sweetness and pathos.

"My Cousin Fanny" employs the device--a little awkward at times, but nevertheless effective--of presenting an exquisite character, almost obscured by eccentricities, and

1 Thomas Nelson Page, "The Stable of the Inn," Scribner's Magazine, 52 (December, 1912), pp. 641-47.

2 Thomas Nelson Page, "Polly, a Christmas Recollection," Harper's Magazine, 74 (December, 1886), pp. 37-52; Polly, a Christmas Recollection (New York: Charles Scribner's sons, 1894).

3 Thomas Nels on Page, "Rachel's Lovers," Harper's Magazine, 88 (December, 1893), pp. 158-61; also included in Pastime Stories.

4 Thomas Nelson Page, A Captured Santa Claus (New york: Charles Scribner's Sons, 1902).

5 Thomas Nelson Page, The Shepherd who Watched by Night (New York: Uharles Scribneris Sons, 1916). 
its influence on young relatives, as seen through the eyes of the unapprectative member:

Christmas . . alway brings up to me my Cousin Fanny; I suppose because she was always so foolish about Christmas. 1

- . She died Christmas night. . She had been riding all day, seeing about a Christmas-tree for the poor chijdren.2

Easily the outstanding story in the group, as it is the most unusual in setting, is "How the Captain Made Christmas." The story is excellent in its simplicity and genuineness. A quiet, kindly old Pullman conductor makes Christmas pleasant for his passengers when their train is stalled in the Shenandoah Valley; among other good results, a romance is helped along. The captain makes a big bowl of eggnog, and toasts, "My friends: all mankind." 3

This toast may be considered as the very essence of the Christmas story according to thomas Nels on Page.

Cooper's Negro boy, enjoying the Christmas generosIty of the white folks, is the forerunner of a long line of dialect stories, which follow nearly the same pattern all

I Thomas Nelson Page, "My Cousin Fanny," In The Burial of the runs, p. 3 .

2 op. cit., p. 36

3 Thomas Nelson Page, "How the Captain Made Christmas," in The Burial of the ciuns, p. 168 . 
through the Jears. "A Christmas Lament"1 is simple reminiscence. "Whar Hy Chris'mus?"2 poses a question. A former slave, now an inmate of the poorhouse, entertains a consumptive Negro boy one stormy Christmas eve by telling of old times, carefree Christmas holidays on the old plantation. He concludes sadiy: "Marse Lincoln gun me freedom. Whar my Chris'mus?" 3

The Negro does not always depend on white charity for his christmas cheer. In "Golden Wedding" by Huth McEnery Stuart4 we find two old neighbors in a New Orleans slum sharing their Christmas dinner for sociability's sake, and gradually recognizing each other as husband and wife, separated long ago in slavery days. The blemish of a superfluous second colncidence does not too greatly impaix the skilful handling of the reunion of the principals; nor the humor

1 Fanny Albert Doughty, "A Christmas Lament," Harper's Magazine, 72 (December, 1885), 166-86.

2 Bierne Lay, "Whar My Chris 'mus?" Atlantic Monthly, 90 (December, 1902), 749-55.

3 op. clt., p. 755. Almost identical in tone is "Cunjur and "Suasion," Atlantic Monthly, 128 (December, 1921), 761-70. As late as 1937 we find, different in plot, but like in its underlying assumption of a benevolent white paternalism, "De Wind an' de Tide," Scribner's Hagazine, 102 (December, 1937), 14-18.

4 Ruth MeEnery Stuart, "Golden Wedding," Harper's Magazine, 80 (December, 1889), 60-75. 
of their punctilious announcement at church the next sunday, when the kindly pastor explains that "golden" wedding implies a generous offering from the congregation.

A dour strain mingles with that of good will when Chris tmas comes to the Appalachian highlands. The reconciliation of a harsh man with his neighbors is the theme of Charles Egbert Craddock's "Way Down in Lonesome Cove;"I and that of a stern man with his neighbors, and consequentiy with his God, is the theme of her later "His Christmas Miracle."2 There is in both of these a suggestion of the supernatural, at least in the subjective effect on the mind of the mountaineer himself. As Jubal enters the cave where the family he has rescued have taken shelter,

- . his eyes were caught first by the aspect of a youthful mother with a golden-haired babe on her breast; close by showed the head and horms of a cow; the mule was mercifully sheltered, too. . A cluster of sheep pressed after the steps of half a dozen men that somehow in the clear-obscure reminded him of the shepherds of old summoned by good tidings of great joy. ${ }^{3}$

"Will ye deny ez ye hev hed a sign from the heavens, Jubal Kennedy?" the old circuit rider straitly demanded. "How could je hev strengthened jer heart fur sech a deed onless the grace o' God prevailed mightily within ye?

1 Mary Noailles Murfree, "Way Down in Lonesome Cove," Harper's Magazine, 72 (December, 1885), 128-46.

2 Mary Noailles Murfree, "His Christmas Miracle," Atlantic Monthly, 108 (December, 1911), 767-75.

3 op. cit., 775 . 
Inasmuch as ye hev done it unto one o' the least o' these my brethren, ye her done it unto me."I

These same elements, reconciliation and the supernatural, appear in another story with a mountain locale, "Christmas Eve on Lonesome," by John Fox, Jr., whose opening paragraph illustrates a curious abuse of the principle of the influence of the blessed season, which smacks not a little of superstition:

It was Christmas Eve on Lonesome. But nobody on Lonesome knew it was Christmas Eve. . . There was the holy hush in the gray twilight that comes only on Christmas Eve.2

Actually, however, there is not so much mere magle in the plot as this opening paragraph would indicate. Although Buck has forgotten the date, he is in reality motivated by an occurrence of the preceding Christmas.

The Christmas Story in Now England. Branch speaks of "the cultural lag in New England in this matter of Christmas cheer," which is "a poignant thread in several of liary wilkins Freeman's stories."3 The term "cultural lag" is an understatement. Mrs. Freeman's characters, says Pattee,

1 "Christmas Miracle," p. 775.

2 John Fox, Jr., "Christmas Eve on Lonesome," in Christmas Eve on Lonesome and Other Stories (New York: Charles Scribner, S Sons, 1904), p. 3 .

3 Branch, op. cit., p. 4. 
are gathered from

- . that terminal moraine of human specimens which the ivew England glacial period of puritanism had left in its wake: abnormalities of conscience... the sensitiveness born of isolated environment become the very essence of sullen pride and egotism. I

A contrast between these stories and those of such a genial writer as Ihomas Nelson Page appears in their treatment of the same situation: How to dispose of a lonely, broken-down old minister. Mr. Page generously permits him to die in his pulpit, at the close of his Christmas sermon, in the consciousness of well-doing.2 Mrs. Freeman leaves him trudging along a snowy road, remorseful for the loss of his honesty--although she allows the reader a comforting hint that he will yet find friends and happiness. 3

"Her favorite theme," continues Pattee, is revolt. -. Sometimes the force is external. . but more often it is internal."4 In such a situation, Christmas cheer is something to be wrested from a bleak environment, something to be cherished jealously, as a feeble spark. ithis spark is

I Fred Lewis Pattee, "On the Terminal Moraine of New England Puritanism," in Side-Lights on American Literature (New York: The Century Co., 1922), pp. 184-85.

2 Page, The Shepherd Who Watched by Night.

3 Mary E. Wilkins Freeman, "The Last Gift," in The Givers (New York: Harper \& Brothers, 1904), pp. 266-96.

4 Pattee, op. cit., p. 207. 
the central warmth of the Christmas story, here almost overpowered by the iminence of the surrounding chill. Out of twelve Christmas stories, only two lack the element of conflict, and these are the only two which are not convincing. ordinarily the author permits the struggle to be successful, and the result is a grim exhilaration.

"A Church Mouse" gives the feel of this bleakness, and of the triumph which results from winning a scant but dear victory. Old Hetty Fifield, after defying the powers of church and town for three months, finally wins permission to be church sexton and to keep house in the vestry. "On Christmas Eve Hetty had reached what to her was the floodtide of peace and prosperity."I Waking early next morning, she gives vent to her jubilation by ringing the church bells. ivever before had a christmas bell been rung in this village; Hetty had probably never heard of Christmas bells. She was prompted by pure artless enthusiasm and grateful happiness. 2

Again, Christmas celebration, especially Christmas giving, may be a form of sex compensation, or of sublimation. This is true in the cases of Christmas Jenny and of Araminta. of the former, a mountain women who makes her living selling

1 Mary E. Wilkins Freeman, "A Church wouse," in A New England Nun and Other Stories (New York: Harper \& Brothers, 1891), p. 425 .

2 op. cit., p. 426. 
vegetables and Christmas wreaths, and who cares for birds and wounded animals, a neighbor woman says:

"They tell about her bein' love-cracked.. . I do know one thing--if she did get kind of twisted out of the reg'lar road of lovin', she's in another one, that's full of Iittle dumbies.. " an' lame rabbits."

Araminta is another woman who has been jilted:

"I am going to make a Christmas present,' says Araminta, and she laughed just as pleasant.

"To that girl?' says $I$.

"Yes," says she... 'a man and a fan." 2 - "I néver saw anybody take so mich comfort in giving Christmas presents in all my life," said the cousin.

Araminta laughed. "Sometimes it seems to me as if I was emptying all the baskets into my own heart and didn't really give anything." 3

Most pathetic of all are those stories in which the conflict is not with the environment alone, but with the moral code. Such is the story of Marg'ret Poole, who steals a package at the store on christmas eve to supply presents for her grandchlldren, and who attempts to atone in various ways. 4 Such is the story of the minister, thwarted by poverty in

1 Mary E. Wilkins Freeman, "Christmas Jenny," in $\underline{A}$ New England Nun, pp. 172-73.

2 Mary E. Wilkins Freeman, "'he Chance of Araminta," in The Givers, p. 225 .

3 op. cit., p. 228.

4 Mary E. Wilkins Freeman, "A Stolen Christmas," in A New England Nun, pp. 321-37. 
his natural bent toward generosity, who takes half the money found in the pocket of an old coat given him by a more favored brother minister, to help a destitute family.1 "The poor minister was alone on a storny road on Christmas-eve. . He had given the last gift which he had to give--his own honesty."2

It is noteworthy that both Miarg'ret and the minister, tortured as both were by remorse, had nevertheless experienced a certain exaltation in the moment of decision. Mrs. Freeman is here putting the accent on the human, current at that time, and given classic form in the decisions made by van Dyke's other Wise Man. 3

The revolt hinted at in 1891, in process in 1904, is complete in "the Gospel According to Joan," published in 1919. In this story, with its almost farcical elements, a thirteen-year-old girl steals the fancy work which a stingy woman has made for Christmas gifts, and sells it back to her, to make money to provide food and Christmas happiness for a family of orphan children. the adults are so dumbfounded by her cool admission, that they give her more money. Joan explains :

1 Freeman, "The Last Gift."

2 Op. cit., pp. 295-96.

3 cf. post, Chap: V. 
"They are her own things, and she has them back. . The lady didn't give the money in the first place, so, of course, I had to see to it."I

As she leaves, to cook supper for the children, the minister, still dazed, exclaims:

"There she goes, little anarchist, holy-hearted in holy cause. . . It may be that breaking the stone letter of the law in the name of love, is the fulminate which shatters the last link of evil which holds the souls of the world from God."2

The Christmas Story Surveys the Slum. While in some cases "color" seems to be given us for its own sake, we find one collection of stories which carry us into unfamiliar territory for Irankly propaganda purposes. This is Christmas Stories, by Jacob Kiis. 3 Branch speaks of the - . horde of little slum-brats [who] make shrill and irresistible demand on one's reading time . . Some of the stories are viscous enough to candy a flapjack; it doesn't matter. 4

"Merry Christmas in the Tenements" is a series of pictures of courageous mirth:

- . There is scarce bread in the house, but the spirit of Christmas has found her attic. Against a broken wall is tacked a hemlock branch, the leavings of the corner

1 Mary E. Wilkins Freeman, "The Gospel According to Joan," Harper's Magazine, 140 (December, 1919), p. 88.

2 Ibid.

3 Jacob Rils, Christmas Stories (New York: The Macmillan Company, 1897, 1923).

4 Branch, op. cit., pp. 24, 28. 
grocer's fitting block; pink string from the packing counter hangs on it in festoons. I.

"What the Christmas Sun Saw in the Tenements"2 is the chill reverse of the same picture, showing only cruelty and misery. "The Kid Hangs Up His Stocking" 3 has more plot: The youngest Inmate of the newsboys' refuge trustingly hangs up his ragged stocking; the other boys, through sacrifice or theft, secure enough toys to fill it.

One step higher in the economic scale, and none the happier for it, are the New York dwellers of 0 . Henry's "The Gift of the Magi"4 and "An Unfinished Christmas Story."5

The flrst is "the uneventful chronicle of two foolish children in a flat who most unwisely sacrificed for each other the greatest treasures of their house." 6 Although the story exhibits less of "color" than of 0 . Henry, it is suf-

1 Rits, op. cit., p. 90 .

2 op. cit., pp. 123-37.

3 op. cit., pp. 1-7.

4 William Sidney Porter, "The Gift of the Mag1," in The Four Million (Doubleday, Page \& Company, 1903), pp. 1625.

5 William Sidney Porter, "An Unfinished Christmas Story," in Rolling Stones (Doubleday, Page \& Company, 1911), pp. $174-80$.

6 "Gift of the Magi," p. 25. 
ficiently accurate in its details of life in the eight-dollara-week flat to give the effect of reality. The charm which has made the story a minor classic is there not so much because of the cleverness and the touches of realism, but in spite of them.

The second of these stories begins: "Now a Christmas story should be one,"I and proposes to deal with the man to whom "Christmas seems to be only the day before the twentysixth day of December," 2 not the economically secure, nor the very poor who receive charity, but the underpaid clerk in the drab rooming house. The rambling story gives little evidence that, if completed, it would have fulfilled these promises.

Three other Christmas stories, the scenes of which are laid in the West ${ }^{3}$ and South, 4 are flimsy contrivances, In which the change of heart strains the credulity.

1 "Unfinished Christmas Story," p. 174.

2 op. c1t., p. 179.

3 william Sidney Porter, "Christmas by Injunction," in Heart of the West (Garden City: Doubleday, Doran \& Company, Inc., 1904, 1935), pp. 270-86. "A Chaparral Christmas Gift," in Whirligigs (New York: Doubleday, Page \& Company, 19io), pp. 223-30.

4 William Sidney Porter, "Whistling Dick's Christmas Stocking," in Roads of Destiny (New York: Doubleday, Page \& Company, 1910), pp. 311-34 
The Christmas Story Along a French By-Path. One of the most exquisitely written stories encountered in the study is an exotic, defying classification in the main current of Anglo-American Christmas Tradition. "The Worker in Sandalwood"I has no suggestion of Dickens; nor does it follow the van Dyke pattern of the religious Christmas story; but it has rather the childlikeness of the old French noels. Where the Other Wise Man earns his vision of the King through years of service, 2 Hyacinthe, through no special merit of his own, is graciously vouchsafed a miracle at the hands of the wandering Christ-Child. The background and idiom of the Province of quebec give the story solidity; and the touch of modern skepticism on the part of the cure'serves as a foil to the simple faith of the apprentice Hyacinthe. The Stranger is handled excellently: not marred by sentimentality, allowed to reveal his identity in various unmistakable ways, and his direct discourse held to a minimum:

He thought the stranger was.singing as he worked, for there seemed to be a sense of some music in the shed, though he could not tell whether it came from the other boy's lips, or from the shabby old tools as he used them, or from the stars.

Then the stranger smiled again, and laid $\dot{a} \dot{d} \dot{i}$ the tools neatly in order, and, opening the door quietly, went away

1 Marjorle I. C. Pickthall, "The Worker in Sandalwood," Atlantic Monthly, 104 (December, 1909), 786-89.

2 Cf. post, Chap. V. 
into the woods.

- . The sun, not yet risen, sent his first beams upon the delicate mist of frost .. . and so all the world was aflame with splendid gold. Far away down the road a dim figure seemed to move amid the glory...

[Hyacinthe] was too pure of heart to feel afraid. "Blessed be the Lord," whispered [he]... "But who will belleve?"

Althaugh the foregoing makes no claim to being an exhaustive study of the regionalistic treatment of the American Christmas story, it is nevertheless evident from this crosssection that while externals differed, the essence of the Christmas story underwent little change. While some writers depended too much on custom and too little on plot, the varying American scene served to enrich greatly the American Christmas story. Such authors as Mary E. Wilkins Freeman and ihomas Nelson Page were able not only to capture the outer aspects of the celebration of their regions, but to make these outer aspects a true expression of the inner spirit.

During the entire period, the Christmas text of peace and good will--the human emphasis, manifested in reconciliation, reunion, or simple sociability--remained the

1 P1cktha11, op. cit., p. 789. 
prevalling theme. ${ }^{1}$ As in the Irving sketches, the interest centered upon the external and concrete rather than upon any underlying philosophy; and warmth, rather than cold, was the prevaling spirit of the Christmas story.

1 The rather cloying sameness was spiced from time to time by stories which reversed or parodied the familiar pattern, not for purposes of satire or irony, but simply in the good old American tradition of finding fun in anything that takes itself too seriously. For an early and a late instance, see Hayden Carruth, "The Premature Prodigal," Harper's Magazine, 90 (December, 1894), 165; and Ring $W$. Lardner, "The Facts," in How to Write Short Stories (New York: Charles Scribner's Sons, 1925), pp. 3-43. 


\section{CHAPTER V}

HENRY VAN DYKE: THE RELIGIOUS EMPHASIS 


\section{CHAPTER V}

\section{HENRY VAN DYKE: THE RELIGIOUS EHPHASIS}

HaIf a century ago-and half a century after the appearance of Dickens' A Christmas Carol--Henry van Dyke pubIished The Story of the Other Wise Man, 1 his best-known Christmas story, and "the best-known American Christmas story."2 Through this, and the christmas stories and essays which followed it, van DJire established a new pattern, dealing less with the external and sensate, than with the underlying message, while continuing the traditional emphasis of central warmth as opposed to cold.

One of the most famous eulogies of Dickens' Carol was that of Jeffrey: "You have done more good by this 11ttle publication than can be traced to all the pulpits and confessionals since Christmas 1842."3 It is interesting that the only American story which occupies a comparable position

1 Henry van Dyke, "The Story of the Other Wise Man," Harper's Magazine, 86 (January, 1893), 277-82. The Story of the Other Wise Man (New York: Harper and Brothers, 1895, 1923).

2 Grant C. Knight, American Iiterature and Culture (New York: Ray Long \& Richard K. SmIth, Inc., 1932), p. 306.

3 cit. John Forster, The Life of Charles Dickens (New York: Charles Scribner's Sons, I902), I, 345. 
should be very closely connected with the pulpit, and that its author did much toward bringing the religious message of Christmas not only into literature, but into the churches as well. The Carol was, in effect, a sermon; The Story of the other Wise Man was a sermon in fact; read for the first time at the Christmas morning service of the Brick Presbyterian Church, New York. I

Dickens in his Christmas stories and other writings personified and helped to influence the period of humanitarianism and reform legislation in England. Van Dyke, half a century later, is inseparable from the humanitarian emphasis which formed a vital element in the various theological and ecclesiastical movements of late nineteenth century America.

It was a period characterized by movement. As the controversy occasioned by the statement of the theory of Evolution was passing out of the acute stage, that which developed from its logical conclusion--the application of historical criticism to the Bible--was beginning.2

1 Tertius van Dyke, Henry van Dyke: a Blography (New York: Harper \& Brothers, 1935), pp. xili, 194.

2 Dores Robinson Sharpe, Walter Rauschenbusch (New York: The Macmilian Company, 1942), pp. 5-6. Samuel McCrea Cavert and Henry Pitney Van Dusen, editors, The Church Through Half a Century (New York: Charles scribner's Sons, 1936), chapter III. 
The displacements attendant upon the American "period of industrial and social adolescence,"I demanded of the Church a social application of its teachings.2 With the waning interest in doctrine as such, and with the rise of the new ogre Higher Criticism, 3 certain inherited phobias, such as the Protestant fear of Rome, began to subside; this, plus "the swift spread of culture," "could not fail to affect the form of public worship."4

these are some of the elements affecting, and expressed in, the writings of Henry van Dyke, and to which his writings to some degree gave further impetus.

Not that van Dyke was a leader of any specific movement. His flair was for the scholarly, the gracious, and the practical, rather than for the speculative and the controversial. When he became involved in theological contro-

\section{1 sharpe, op. cit., p. 4.}

2 Op. cit. Chapter I, et passim. Cavert and Van Dusen, op. c1t.' Chapter V.

3 ". . In our day, in which the fact of the incarnation of christ is so bitterly and persistently attacked, wo need the testimony of the Christian world to its belief in the superhuman birth of the Master, in same public avowal, like that which the proper observance of [Christmas] affords." Editorial in The Christian Observer (Louisvilie), December 12, 1906. For the contrast of this statement with the observer's earlier policy, cf. post, p. 71 .

4 Cavert and Van Dusen, op. cit., p. 185. 
versy, as in the notorious briggs heresy case, I it was largely as a defender of liberty of thought; 2 and "when asked if he were a liberal or a conservative, replied passionately II am a comprehensionist. 33 when he attacked the theory of infant damnation, hoping to lay the matter once for all, it was as a humane man that he spoke.4

In the social application of Christianity, he occupied a position in advance of that of the majority of his contemporaries, but not in the forefront. the biographer of such a flaming social prophet as Walter Rauschenbusch comments with some scorn: "Henry van Dyke, who was in his heyday, never got nearer to social Christianity than a sermon on "International Copyright." 5 This comment, to be sure is not accurate. 6 His position may be fairly sunmed up in his own words: "The church may well have a soupkitchen if it is needed; but the church ought never to be a
1 Van Dyke, Chapter IX
2 op. cit., p. 129.
3 op. cit., p. 132
4 Henry van Dyke, God and Little Children, (New York: Ans on D. F. Randolph and Co., 1890).

5 Sharpe, op. cit., p. 123.

6 Van Dyke, Chapter VIII. 
soup-kitchen." 1 Henry Sloane Coffin includes van Dyke in a list of nine writers of hymns with social implications.2 To discover how the name of Henry van Dyke became primarily linked with one Christmas story, it is necessary to go behind these public trends, essential as they are, to a consideration of the man's home life. The spirit of the manse of his childhood was cultured, happy, and tolerant. 3 It is noteworthy that his boyhood heroes were his father, Robert $\mathrm{E}$. Lee, and Alfred Tennys on. 4

In that home Christmas was regularly celebrated. The omphasis was on the religious aspect of the day, 5 an unusual thing at that time. While his biographer warns against crediting van Dyke's later interest in the day to "childish memorles of festivals" rather than to religious conviction, 6 it is nevertheless not improbable that these early memories helped to shape the expression of that con-

1 Henry van Dyke, "The Church in the City," in Essays in Application (New York: Charles Scrioner's Sons, 1905), p. IT.

2 Cavert and Van Dusen, op. cit., p. 200

3 van Dyke, Chapter II.

4 op. cit., p. 26.

5 Tertius van Dyke, letter dated Febmuary 25, 1943.

6 Loc. c1t. 
viction. The Nativity story entered his consideration of a wide variety of subjects. In God and Little Children be wrote: "At His manger--cradle we have learned the meaning of the Gospel for Iittle Children." I In his essay "Is the World Growing Better?" he concluded:

- When Christmas comes I shall sit down with John Friendly to enjoy its cheer, rather than with any sour pessimist. . The hope of humanity lies in the widening, deepening influence of that blessed Life which was born nineteen hundred years ago in Bethlehem."2

Whether or not van Dyke owed any of his tolerance to his "Iong line of solidly Dutch ancestry," 3 he liked to think that he did, and to think of himself as a "Typical Dutchman."4 Such a tradition might indirectly have contributed to an appreciation of Christmas. Although the Dutch St. Nicholas celebration was originally entirely apart from the English Christmas, it had gradually been absorbed into the latter; thus, as has been noted in the case of Irving, 5 any one versed in the former tradition might unconsciously be pre-

1

op. cit., p. 40 .

2 Essays in Application, pp. 34-35

3 Van Dyke, p. 3.

4 Henry van Dyke, "The Typical Dutchman," Moderm Eloquence, Ashley H. Thorndike, editor (New York: LIncoln Scholarship Fund, Inc., 1928), III, 363-67.

5 cf. ante, p. 3-4. 
disposed to a favorable attitude toward Christmas.

His life-long efforts to enrich the worship of the church may be traced both to his tolerance and to his culture. Closely allied with form of worship is the observance of seasons, notably in this case that of Christmas:

His concern with questions of worship was continuous. Gradually he had been enriching the order of service in the Brick Church . . . In 1888 he had inaugurated the custom of holding a service in the church on the morning of Christmas Day at which, during the latter years of his pastorate, he was accustomed to read a new story or poem of his own. 1

That this innovation was viewed with alarm by the more conservative elements, is shown by an editorial in the Christian Observer, as late as 1899.2

Such is the background for the composition of The Story of the Other Wise Man, and a long line of Christmas stories and essays. His first published story, "The oak of Gelsmar"3 which appeared in 1891, is also a Christmas story; having as its basis an incident of church history, it has more action, though less philosophy, than the

\section{Van Dyke, p. 194.}

2 Editorial in The Christian Observer (Louisville), January 27, 1899.

3 Henry van Dyke, "The Oak of Geismar," Scribner's Magazine, 10 (December, 1891), pp. 681-87. Later known as The First Christmas Tree. A Story of the Forest (New York: Charles Scribner's sons, $18 \overline{97,1914 T, 76}$ p. 
Other Wise Man, and is probably van Dyke's second best known piece of writing. However, it is with the philosophy of the Other Wise Man that we must deal to see the author in relation to his period.

The autumn of 1892 was a time of sickness, of personal grief in the death of his father, and of the strain of theological controversy.

One anguished, sleepless night there came to him "suddenly and without labor" The Story of the Other Wise Man. Patiently in the following months, he gathered the detailed knowledge that the teling demanded. 1

He felt that the story had been "given" to him-not indeed by "direct inspiration" as he was frequently and wrongfully described as claiming. 2

The story was read at Brick Church on Christmas, 1892, and published in Harper's Magazine for January, 1893. Van Dyke later subjected it to thorough revision. When it appeared in book form in 1896 it had been greatly amplified and strengthened: involved sentences had been divided, and direct discourse substituted for indirect. Although the author had not at that time visited Palestine, 3 he derived much from

1 Van Dyke, p. xiii.

2 op. cit., p. 390 .

3 Henry van Dyke, Out of Doors in the Holy Land (New York: Charles Scribner's Sons, 1908), pp. Ix-x. 
a journey to Egypt in 1894.1 He himself said of the work on the story:

If the story itself came without effort, the writing of the story was a serious piece of labor?. . For the brlef description of the ride to Babylon I read nine volumes of travel . . for the journey in the desert I made a day's excursion in the wilderness behind Assouan.2

It was in the situations presented in the story, and In Artaban's decisions, that van Dyke captured the spirit of his time. ${ }^{3}$ It was the opponent of infant damnation-- the humane man who challenged a harsh doctrine which was the reductio ad absurdum of a theological abstraction--who, despite his claim to the contrary, created the scene at Bethlehem: -. I have boen asked many times why I made the Fourth Wise Man tell a lie, in the cottage at Bethlehem, to save the little child's life.

I did not make him tell a lie.

What Artaban said to the soldiers he said for himself, because he could not help it.

Is a lie ever justifiable? Perhaps not. But may it not sometimes seem inevitable?

\section{Van Dyke, p. 151 . \\ 2 op. c1t., p. 242 .}

3 The Fourth Wise Man sets out on his journey to Bethlehem bearing as his gift to the King three jewels. Three times Artaban faces the question of "spending for man that which was meant for God." Each time urgent human need triumphs. The last decision is made in Jemusalem on the day of the Crucifixion. Dying, the old man has a vision of the King, and receives the comforting message: "Inasmuch as thou
hast done it unto one of the least of these. 
And if it were a sin, might not a man confess it, and be pardoned for it more easily than for the greater sin of spiritual selfishness, or indifference, or the betrayal of innocent blood? That is what I saw Artaban do.I

The human emphasis in the three decisions interpreted, better than books or sermons on the social gospel, the growIng sense of social responsibility as opposed to a religion which was purely individual:

It was the old conflict in his soul.. the conflict between the expectation of faith and the impulse of love. Twice the gift which he had consecrated to the worship of religion had been drawn from his hand to the service of humanity...

One thing only was sure to his divided heart-to rescue this helpless girl would be a true deed of love. And is not love the light of the soul? 2

The Other Wise Man has had numerous imitators. As Lew Wallace noted, these mysterious Eastern visitors have an uncanny fascination. The Folly of the Three Wise Men, 5

\section{1 other Wise Man, pp. xiii-xiv.}

2 op. cit., pp. $72-73$.

3 The wide reading, for more than a decade previous, of Lew Wallace's Ben-Hur (New York: Harper and Brothers, 1880), an inferior book but a vastly popular one, would have served to prepare the reading public to accept an imaginative interpretation of the Bible narrative.

4 Lew Wallace, Lew Wallace; an Autobiography (New York: Harper and Brothers, 1906$)$, II, 926.

5 Edgar Whitaker Work, The Folly of the Three Wise then (New York: George H. Doran Company, I915) 
The Lost Star, 1 and The Man at the Gate of the World 2 are only a few which play variations on the same theme: that of finding the King through service to man.

Van Dyke wisely did not try repeat this subject. "The Sad Shepherd" 3 and "Let Us Go Even Unto Bethlehem," 4 while imaginatively filling in the events of the Gospel story, differ from the earlier tale in theme and characters, as does also The Lost Boy, 5 not strictly a Christmas story, but from its nature closely related to this group. "The Lost Word," 6 like "The First Christmas Tree," has a back-

1 David DeForest Burrell, The Lost Star (New York: Fleming H. Revell Company, 1916)

2 W. E. Cule, The Man at the Gate of the World (Boston: Hale, Cushman \& Flint, I929)

3 Henry van Dyke, "The Sad Shepherd", in The Unknown wuantity (New York: Charles Scribner's Son', 1912), pp. 287322.

4 Henry van Dyke, "Let Us Go Even Unto Bethlehem", Delineator, III(December, 1927), 6-9, 75-76.

5 Henry van Dyke, The Lost Boy (New York: Harper and Brothers, 1913). "The Boy of Nazareth Dreams", in The Valley of Vision (New York: Charles Scribner's Sons, 1919), pp. 259306.

6 Henry van Dyke, "The Lost Word", in The Blue Flower (New York: Charles Scribner's Sons, 1898, 1902), $\frac{\text { pp. }}{209-57 .}$ 
ground of Church history. "The Mansion"l and "The Hero and Tin Soldiers"2 are modern in setting, dealing with the ageold problems of wealth and of war.

Like most Christmas stories, all these have the familiar theme of peace and good will. their greater solidity, as compared with the average Christmas story, lies In part in their greater artistic merit. It may lie also in the fact that van Dyke has rediscovered the major premise of that text: "Glory to God in the highest." Thus their humanitarianism has an adequacy of motivation which is lacking in more superfictal stories.

Here, then, is Henry van Dyke's contribution to the Christmas story: His discovery of the attractiveness of the religious values of Christmas; and his achievement in making these values clear both to the average reader, and to the church.

1 Henry van Dyke, "The Mansion", Harper's Magazine 122 (December, 1910), 3-17. Also included in The Valley of Vision, $\mathrm{pp} .325-70$.

2 Henry van Dyke, "The Hero and Tin Soldiers," In The Valley of Vision, pp. 231-36. 


\section{CHAPTER VI}

JAMES LANE ALLEN: ACCENT ON CHILT 
CHAPTER VI

JAMES LANE ALLEN: ACCENT ON CHILL

The three Christmas stories of James Lane Allen, The Bride of the Mistletoe, 1 The Doctor's Christmas Eve, 2 (parts of an uncompleted Christmas trilogy3), and The Last Christmas Tree, 4 occupy an unusual place in American Christmas fiction. Unlike the Dickens tradition of good will, spiritualized by van Dyke, they are pessimistic and chilling. Allen reverses, as did Hawthorne, 5 and, to a lesser extent, Mrs. Freeman, 6 the customary relation of warmth and cold. Instead of warmth at the center of the story, with its effect heightened by a background of snowy landscape without, such warmth as there is merely intensifies the coldness of the main subject. Yet these stories are not iconoclastic, they

\section{James Lane Allen, The Bride of the Mistletoe (New} York: The Macmillan Company, 1909).

2 James Lane Allen, The Doctor's Christmas Eve (New York: The Macmillan Compan

3 Grant C. Knight, "Allen's Christmas Trilogy and Its Meaning," The Bookman, 68(December, 1928), 411-15.

4 James Lane Allen, The Last Christmas Tree, and Idyl of Immortality (Portiand, Me.: Thomas Bird Mosher, 1914).

5 Cf. ante, Chap. III

6 Cf. ante, pp. 53-58. 
do not seek to overthrow the institution of Christmas nor are they marred by any cheap cynicism.

Though Allen's emphas is in these stories is primarily on the ideational rather than on the sensate, he does make large appeal to the senses.

In the first place, Allen, the admirer of "Keats... who of all the world's poets felt the things that pass,"I takes delight in the tactual warmth and spicy fragrance of Christmas.

In the second place, Allen was attempting to write local color. A friend and staunch admirer recounts that he once ventured to observe to the author that

- . the theme of [The Doctor's Christmas Eve] was more universal than local, whereupon he said, as I recall it;

"Yes, that is true. The serial of the nation must be told in terms of its states"2

His insistence on Kentucky consequently seems self-conscious and dragged-in; he is almost as much of a local patriot as one of the appalling juveniles of The Doctor's Christmas Eve:

"Oh, bother!" said Harold, the Kentucky Saxon ... "we have everything in Kentucky that they had, and more besides. They can keep their Dickens." i. We have pienty of American cratchits, just as

1 Bride of Mistletoe, p. 138; ce. Allen's poem, "On the ManteIpiece," The Bookman, 50 (September, 1919), 91-94.

2 Isaac Marcosson, Adventures in Interviewing (New York: John Lane Company, 1925), p. 230. 
good--and much worse."I

An odd inconsistency is found in the fact that though Allen claims time and again in the Trilogy to be depicting a "Kentucky Christmas," the chill of the stories belies this claim. For "Kentucky Christmas" as he defines it here and elsewhere has warmith at its heart:

- . One spirit of preparation, one mood of good w111, warmed houses and hearts. The whole visible heaven was receiving the incense of Kentucky Christmas fires.2

The tell-tale Christmas smoke of the land was pouring from its chimneys. 3

His biographer, in listing about a dozen elements of the Kentucky scene at the time of Allen's birth, mentions ii - Christmas festivities when the entire land was blue with the smoke from smokehouses." 4 It is significant that this sentence was adapted from one of Allen's attempts at

1 Doctor's Christmas Eve, pp. 238-39. That this was not actualiy AIIen's owm attitude is proved by his statement to the New York Times, in January, 1914, that Dickens' A Christmas CaroI was, "for all 1ts faults, the best short story In EngIish." Grant C. Knight, James Lane Allen and the Genteel Tradition (Chapel Hill: University of North Carolina Press, 1935), p. 198.

$$
\begin{aligned}
& 2 \text { Doctor's Christmas Eve, p. } 2 . \\
& 3 \text { Op. c1t., p. } 24 . \\
& 4 \text { Knight, Allen, p. } 6 .
\end{aligned}
$$


autoblography. I

Again, in the swan-song, "The Landmark," occurs a similar passage. The mother of a son leaving Kentucky pictures an autumn, a Christmas, and a spring scene he will miss:

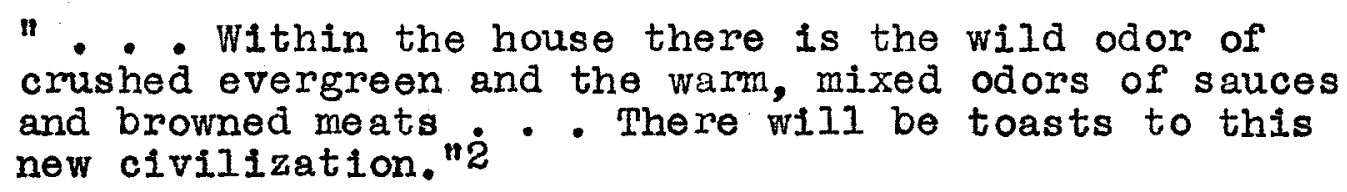

A hint, if not of warmth, then at least of geniality, appears in the description of the Christmas traffic: "Every vehicle Christmas-laden: signs and foretokens of the Southern Yuletide." 3

Allen's conception of the feast seems to have been formulated during his lengthy investigation of "Christmas customs and allied pagan rites."4 He makes a pronouncement of his creed in the opening pages of The Bride of the Mistletoe:

What is Christmas? and what for centuries has it been to differing but always identical mortals?

1 Grant C. Knight, letter dated March 1, 1943.

2 James Lane Allen, "The Landmark," The Landmark (New York: The Macmilian Company, 1924), pp. 64-65.

3 Bride of the Mistletoe, p. 48.

4 Knight, "Trilogy," p. 414. 
It was once - . the old pagan festival of the reappearing sun . . It was the pagan festival to honor the descent of the fabled inhabitants of an upper world upon the earth . . . It is now the festival of the Immortal Child appearing in the midst of mortal children. - . It has latterly become the widening festival of universal brotherhood with succor for all need and nighness to all suffering ...

And thus . . Christmas is the festival of the better worldiy self. But better than worldliness it is - . the symbolic Earth Festival of the Evergreen; setting forth man's pathetic love of youth .. . and renewing his faith in a destiny that winds its ancient way upward.1

In two slips of paper "In an envelope containing papers connected with The Bride of the Mistletoe,"2 Grant C. Knight discovered the Rosetta Stone of the otherwise unintelligible Trilogy. 3 The first clue is a nowspaper clipping; an old German legend recounts that - When Eve plucked the fatal apple the leaves of the tree immediately shrivelled into needle points only on Christmas does it bloom brightly ... The curse is turned into a blessing by the coming of the Christ ChIld. 4

The second clue is Allen's outline, jotted down in 1909: THE DAY WE EARN

\footnotetext{
1 Bride of the Mistletoe, pp. 8-9.

2 Knight, "Trilogy," p. 414.

3 Knight, letter, March I, 1943.

4 Knight, "Trilogy," p. 415; Allen, p. 170.
} 


\author{
A Three Part Story \\ I. The Bride of the Mistletoe \\ --the Woman \\ note of the Mortal \\ II. A Brood of the Eagle \\ - The Children \\ note of the immortal \\ III. The Pledge of the Evergreen \\ - The Man \\ Mortal and immortal
}

Notes--The day we all earn--we have earned ours together.1

The second book was printed under the title the Doctor's Christmas Eve; Allen later announced the title of the third--which was not to be fiction, and which never material1zed--as The Christmas Tree: An Interpretation. 3

The Eve-legend is the clue to Mrs. Ousley's spiritual struggle in The Bride of the Mistletoe, as this passage demonstrates:

She started to take the shorter way but thought of the parlor and drew back . . The evergreen there in the middle of the room--it became to her as that tree of the knowledge of good and evil which at creation's morning had driven woman from Paradise.4

The legend appears again in The Doctor's Christmas

1 Knight, "Trilogy," p. 415; Allen, p. 171.

2 Doctor's Christmas Eve, p. vii

3 Knight, Allen, p. 173.

4 Bride of Mistletoe, pp. 171-72. 
Eve, through which

runs the idea of a child's turming a curse into a bles-. sing, the concept of a Christ-child, and it is this idea, not Allen's sentimentality, that requires the death of the doctor's son. I

This is made clear in the doctor's feeling, at Herbert's death, that the child has been made the scapegoat, to bear his father's sins; 2 and in the description of the stone at the boy's grave:

- . The ancient stone with its legend of atonement and the young tree thus brought together stood there as if the of fending and the innocent had come to one of their meeting places. 3

The triple form of the outline gives meaning to such

a passage as this:

The usual hour of his return from college was three in the afternoon. She had symbolized that hour; one stroke for him, one for her, one for the children--the three in one--the trinity of the household. 4

Had Allen made public the Eve-legend and the outline, had he permitted the reader to peep in the back of the book for the answer, less misunderstanding might have'arisen, and he might not have been discouraged from completing the Tri-

1 Knight, "Trilogy," p. 415; Allen, p. 172.

2 Doctor's Chris tmas Eve, p. 296.

3 ㅇp. cit., p. 297.

4 Bride of the Mistlet oe, p. 174. 
logJ. Had it not been for the Christmas wrappings of the tale, the contents of the package might have caused less shock. After all, it is disconcerting to expect a story in the Dickens or the van Dyke tradition, and to find instead an account of marital infelicity, unrelieved by a happy ending, and adorned with not-too-subtle orgiastic symbols. The two books cost Allen a good deal of his popularity. 1

The most important article in the Christmas creed formulated by Allen" is the definition of the day as "the symbolic Earth Festival of the Evergreen." The shadow of one small fir tree Iles across the pages of two books. It is Interesting that, in referring to the Christmas tree, the word "Tree" is always capitalized.

In The Bride of the Mistletoe, "one of the coldest books in American Iiterature," 3 there is almost an ident1fication of Professor ousley with the Tree.4 ConsequentIy there is something foreboding and sinister about the evergreen whenever it appears. In The Doctor's Christmas Eve, in which there is no sense of ldentification but only of

1 Knight, Allen, pp. 173-74.

2 cf. ante, pp. $8 I-82$.

3 Knight, Allen, p. 116.

4 Bride of the M1stletoe, pp. 63, 90, 126, 130-31. 
personification or of symbolism, there is no such feeling of chill. Though the Ouslejs' Christmas tree does not loom so large in this book as in 1ts predecessor, the references to this and other trees are as numerous, and more varied: On Christmas Eve Dr. Birney overhears his unloved wife singing to herself Lanier's "Ballad of Trees and the Master." Iistening, he realizes her sacrifices for him.1 - Thus her song was not of the Christmas Tree and of the Manger when Divine love arrives; but of the tree of the Crucifixion and of love's betrayal and sacrifice ere it goes away.

The Christmas Tree appears in personified form, but in more playful mood:

Through the large empty keyhole of the locked doors an object was making its way: first one long green finger appeared, and then a second, and then a third-Those three sacred fingers-as old as Buddha! . . The fingers and arm taken together constituted a broken-off bough of the Christmas Tree.2

Santa Claus appears in an unfamiliar and unsuspected role as "the forest god," 3 and "the white-haired Winter-god, Forest-spirit of the earth's children." 4

There is almost identification in the following

1 Doctor's Christmas Eve, pp. 208-10.

2 op. cit., p. 251 .

3 op. cit., p. 259 .

4 op. c1t., p. 269. 
passage, but not quite, since the children are well aware that it is all a make-believe, that it is really their father and neighbor who is impersonating Santa Claus in the dark parlor:

-. [The volce] seemed not so much to proceed from near the Tree as to emanate from the Tree itself--to be the Tree speaking !

And, last, the evergreen is used to symbolize the doctor's dead son, the innocent scapegoat of his father's sins : 2

Beside the memorial stood a young evergreen as the living forest substitute of him sleeping below: it was of about his age and height. 3

Though Allen never wrote The Pledge of the Evergreen (or The Christmas Tree: An Interpretation), in 1914, four years after The Doctor's Christmas Eve, he published in book form The Last Christmas Tree. A briefer sketch, under the same title, had been published in The Saturday Evening Post in 1908. The use of the evergreen troe as the representative of all living things, the marrow-chilling properties of the story, and several echoes of the Trilogy books, point this out as the logical substitute for the unwritten third

1 Doctor's Christmas Eve, p. 267.

2 op. cit., p. 296.

3 op. c1t., p. 297. 
member. 1

Its dedication 1s: "To those who know the have no solution of the universe, yet hope for the best and live for 1t." Its text might have been taken from the statement, quoted before, that Christmas is the Festival of the Evergreen, "setting forth man's pathetic love of youth . . and renewing his faith in a destiny that winds its ancient way upward." 2

The plot of The Last Christmas Tree appears briefly in The Doctor's Christmas Eve, as the Professor, impersonating the "Forest-god," tells the children a story of the time when the earth shall gradually grow cold, and the sun go out like a candle. "Where," he asks, "will all the children of the earth be then?" and each self-confidently replies, "I know where I shall be .. . Where will you be?" Gravely the Forest-spirit answers, "Wherever the earth's children are, may I be there with them $!^{\prime \prime}$

"Whatever else it may be," says Allen in The Last Christmas Tree, "life as we know it is warmth. Every living thing is on fire and every fire is perpetually going out." 4

1 Cf. Knight, Allen, p. 172 .

2 Bride of Mistletoe, p. 9.

3 Doctor's Christmas Eve, pp. 277-82.

4 Last Christmas Tree, p. 3. 
Gradually over this earth the polar snows creep closer together. Now, on the last night of earth, two lone fir trees remain as the "final sentinels of Nature." Nearly covered, they realize the end is near. They consider man--the pity of his proud pretensions. I At the very last they seem to feel about them the children of the earth--as the Professor had predicted.2 Thus the tale closes with some scant intimations of immortality--but faint, very faint.

One is loath to suggest that such an exquisite bit of art may be a conscious, or unconscious, travesty; but this story, beginning with warmth and ending with eternal cold, has both in its title and in its closing scene significant points of resemblance and contrast with a Christmas story which, more conventionally, begins with cold and despair, and ends with warmth: The First Christmas Tree.

Here is van Dyke's happy ending:

"And here," said Winfried, as his eyes fell on a young fir tree standing . . amid the divided ruins of the fallen oak, "here is the living tree, with no stain of blood upon it, that shall be the sign of your new worship. See how it points to the sky. Let us call it the tree of the Christ-child. Take it up and carry it to the chieftain's hall. You shall go no more into the shadows of the forest to keep your feasts with secret rites of shame. You shall keep them at home, with laughter and song and rites of love...

1 Last Christmas Tree, pp. 2I-3I.

2 Doctor's Christmas Eve, p. 281; cf. ante, p. 88. 
They kindled lights among the branches... The children encircled it, wondering, and the sweet odour of balsam filled the house.I

Contrast with this the conclusion of The Last Ghrist-

mas Tree:

"Our fathers remembered the day when [man] went into the woods and cut down one of our people and took it into his house. On the evergreen he set the star: They were for his youth and his immortality."

"Be still!" whispered the fir tree above. "At that moment, while you spoke, I felt the soft fingers of a child searching my boughs. Was not this what in human times the $\mathrm{y}$ called Christmas Eve? - "They are ail about me i The are ail about you!: : the last of their Christmas trees. The souls of all children, wide-awake, are gathering about us ere we pass into the earth's sleep." 3

The van Dyke contrast, whether conscious or unconscious on Allen's part, is diametric. The story is not, however, without precedent in American Christmas fiction. $I_{t}$ is, as Knight diagnoses it, "another of the grave moral-

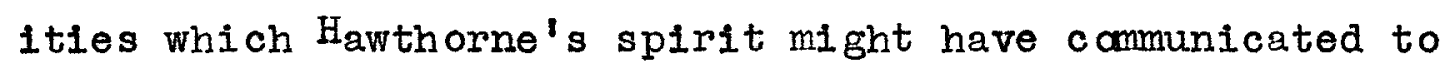
the Kentuckian." "4

1 Henry van Dyke, The First Christmas Tree (New York: Charles Scribner's Sons, 1897, 1914t, pp. 72, 73. The earlie $r$, magazine version of the story is still more striking in paralies: "This little tree, a young child of the forest, shall be your holy tree tonight. . . It is the sign of an endless 7 ife, for its leaves are ever green." "The oak of Geismar," Scribner's Magazine, 10 (December, 1891), p. 686.
2 Last Christmas Tree, p. 32.
3 op. cit., pp. 32-33.
4 Knight, Allen, p. 158. 
The personified use of trees, especially of evergreens, is not confined to the Christmas stories. His biographer wams against the conclusion that "a tree was to him an obsession, a phallic symbol, [or] a racial memory;"l nevertheless, this personification is a recurring theme in his work over a period of at least sixteen years:

A month has gone by since Georgiana passed away. Today, for the first time, I went back to the woods. - - As I approached the edge of the forest, it was as thaigh an invisible company of influences came gently forth to meet me and sought to draw me back into their old friendship. I found myself stroking the trunks of the trees as I wald throw my arm around the shoulders of a tried comrade.2

- - [After a sleet storm] a limb had dropped sheer on the [schoolhouse] steps. . He would be able to tell Gabrielia tonight that.... a new woods scholar, with little feet and $a \mathrm{bIg}$ hard head and a bunch of mistletoe in one hand, was standing on the steps. 3

- - He was leaning on a rough, stout hickory as long as himself. " "I rode. But I am walking now-barely. This young tree is escorting me." 4

"Oh, don't talk to me about trees! What do I care about wood! You're the tree that I want to dig up, and take home, and plant, and live under, and be buried by." 5

1 Knight, letter of March 1, 1943.

2 James Lane Allen, Aftermath (New York: Harper \& Brothers, 1896), pp. 124-25.

3 James Lane Allen, The Reign of Law (New York: The Macmillan Company, 1900), pp. 2द्24-25.

4 op. cit., p. 375.

5 James Lane Allen, The Mettle of the Pasture (New York: The Macmillan Compan $\bar{y}, 1912)$, pp. 234-35. 
- A woman had paused with her face turmed upward toward the balustrade and a tiny evergreen. As I approached she put up one hand and patted it as though it were a human head.

$\therefore$ Here was a woman on a winter night with thousands around her reaching out to the frozen tree . . .--the human hear trying to reach other hearts through images not human. 1

"Trying to reach other hearts through images"--here, perhaps, is a clue not only to Allen's use of trees, but also to his balance of the themes of warmth and cold, in his Christmas stories. At heart these are cold, colder than anything in American Christmas fiction since Hawthorne's "The Christmas Banquet."2 The surface warmth of the Trilogy stories acts as a foil to this chill. But the evident pleasure with which the writer dwells on this warmth suggests that to him 1t was something more than a foil. Allen, who was noarIy as incapable as Gervayse Hastings himself of establishing a permanent, warm, human contact with other human hearts, 3 may be in this way attempting such contacts through the medium of images. Thus he has given us, as the image of life, the tree; as the image of warmth, all the good things which to to make up "Kentucky Christmas."

1 James Lane Allen, The Heroine in Bronze (New York: The Macmillan Company, 1912T, pp. 234-35.

$$
\begin{aligned}
& 2 \text { Gf. ante, Chap. III. } \\
& 3 \text { E. g., Knight, Allen, p. } 67 \text {, et passim. }
\end{aligned}
$$


CHAPTER VII

CUNCLUS IONS 
This study had as its purpose to examine, first, the characteristics of the American Christmas story; and, secondly, the course of its development in American literature.

The Christmas Story: Characteristics. Examination of the material revealed that the typical American Christmas story has, in varying degrees, certain characteristics, sufficiently marked, and sufficiently constant, to establish this class of stories as an independent, minor literary genre. Its central psychological motif is the balance of the themes of warmth and cold. Ordinarily warmth forms the primary, and cold the secondary, theme. Its message is that expressed in the original Christmas text, "Good will toward men." Typically it is a short piece of fiction. The longest story considered in this study, The Doctor's Christmas Eve, a book of 304 pages, fails to achieve unity; The Bride of the Istletoe, by the same author, which observes the classic unities to a remarkable degree, has only 190 pages. The best of these stories are short.

An anthology of the best American Christmas stories, to be representative, well-rounded, yet brief, might well consist of the following items, all of which manifest the 
characteristics of the genre: 1

Irving: Christmas chapters in The Sketch Book (sometimes grouped under the titie, "Old (hristmas"), 1819-20.

Hawthorne: "The Christmas Banquet," 1846.

Harte: "How Santa Claus Came to Simpson's Bar," 1872.

Freeman: "A Church Mouse," 1891.

Page: "How the Captain Made Christmas," 1894.

van Dyke: The Story of the other Wise Man, 1893,

Porter: "Gifts of the Magi," 1903.

Pickthall: "The Worker in Sandalwood," 1909.

Allen: The Last Christmas Tree, 1914.

Broun: "The Shepherd," c. 1926.

The Christmas Story: Trends. The Christmas story in American literature may emphasize either outer action or inner experience; either warmth or cold--that is, either cheer or irony. The variations, while not strictly chronological, were found to operate in broad, general cycles, of three divisions each.

The first, or formative, cycle opens with the Christmas sketches of Irving, occupied with the outer, sensate as-

1 There are numerous Christmas anthologies containing both prose and verse: with folklore, and excerpts from longer fiction, along with Christmas short stories. 
pects of Christmas.

Dickens, after serving an apprenticeship in this same field, developed in the Carol the unifled Christmas tale which was also the Christmas sermon; as the Christmas story of the common people, it had a powerful influence on Christmas in American Iife and literature.

In this group, though not of it, we find Hawthorme's experimental use of cold, rather than the customary warmth, as the central theme.

In the didactic element in Dickens, and in Hawthorne's use of irony, the Christmas story became ideational, rather than purely sensate.

The second cycle followed an almost identical course. The regionalistic writers tried to reproduce the tangible aspects of Christmas as it appeared in its American sceno.

W1th van Dyke, whose The Story of the other Wise Man is generally accorded first rank among American Christmas stories, there appeared--as in the work of Dickens half a century before--the story which was also the Christmas sermon. Finally allen, in his attempted Christmas trilogy, demonstrated his kinship with Hawthorne by experimenting with the reversal of warmth and cold, and by transferring the field of the Christmas story from the sensate to the symbolical. This study has traced the American Christmas story 
down to the First World War. ${ }^{1}$ since then there has been little outstanding fiction. The Atlantic Monthly, which has served as the backbone of the study, has printed only seven Christmas stories in the past twenty years. Moreover, we find today no single author occupying a position comparable to that held by van Dyke about the beginning of the century. On the positive side, we find an increasing amount of nonfictional Christmas material; ${ }^{2}$ this may, or may not, indicate the first stage of a new cycle.

1 A few stories of a later date are included, but only when the author's work as a whole belongs to an earlier period, or when the story represents the continuation of an estabilished convention.

2 In the Atlantic, the ratio of non-fiction to fiction since the First World War has been nearly $3: 1$, as contrasted with approximately 2:3 during the preceding period. The other magazines also show an increase in non-fiction.

The following statement concerning the genes is of the most recent of these Atlantic essays (Llewellyn Howland, "Holly Days," 170:126-28), a reminiscent sketch in the Irving manner, may be significant: "In Mr. Howland's case, the impulse to write his story- a reminiscence of Christmas--came from us, although we left it to him to decide whether it should take the form of short story or an essay." Edward Weeks, letter of May 14, 1943. 
CHRONOLOGICAL IIST 


\section{CHRONOLOGICAI IIST}

CHRISTMAS FICTION IN THE ATLANTIC MONTHLY, HARPER'S MAGAZINE, AND SCRIBNER'S MAGAZINE

The following is a list of all Christmas fiction found in three American magazines of long standing, from their establishment through 1942.

This list is based on the files of the Louisvilie Free Public Library, which have been incomplete since the 1937 flood: Almost the entire decade of the inineties is missing from the file of Scribner's, about half the volumes of the leighties from the Atlantic, beside occasional volumes from all three magazines.

No effort has been made in the way of selection. A few stories are of European authorship; or are chapters in longer works; or are Christmas stories only in the broad sense of mentioning the day--not of being motivated by it.

Those marked with an asterisk (*) are listed in the Bibllography also, and receive attention in the text.

ATLANTIC MONTHLY

(Founded 1857)
HARPER'S MAGAZINE

(Founded 1851)

1851

"A Bachelor's Christmas," 2:399-401.

1852

Charles Dickens, "Christmas in the Company of John Doe," $4: 386-90$.

1857

"Starlight on Bethlehem," 14:299-32. 
ATLANTIC MONTHLY HARPER'S MAGAZINE SCRIBNER'S MAGAZINE

"Our Christmas at the

Pines," 16:48-56.

1859

"Our Christmas Party,"

$18: 202-05$.

1860

Rose Terry, "Mrs.

Anthon's Christmas

Present," 20:186-94.

Harriet $E$. Prescott,

"Yet's Christmas Box,"

$20: 644-59$.

A. Oakey Hall, "The M.

$22: 52-67$.

1861

*A Story of Today,"

$8: 471-86,582-97$,

$707-18$.

1862

"A Story of Today," continued, 9:40-5i, 202-13, 282-98.

1863

Author of Life in Egbert P. Watson, the Iron MIIIs, "The Policeman's "The Promise of the Christmas Tramp," Dawn: a Christmas 26:406-08. Story," 11:10-25.

1864

Author of Iife in the

Iron Mills, "Stephen

Yarrow: a Chris tmas

story," 13:66-88. 
"Five Sisters Court at Christmas Tide," $15: 22-39$.

1866

Author of Iife in the

Iron Mills, "The High

TIde of December,"

17: $47-64$.

1872

*Bret Harte, "How Constance E. [sic]

Santa Claus Came to Woolson, "A Merry

Simps on's Bar," Christmas," 44:23129:349-57. 36 .

Mrs. Frank M'Carthy,

"The Reverend Samps on's

Christmas Gift," 44:273-

76 .

1873

Iucretia P. Hale

"The Two Letters,"

31: 513-30.

\author{
1877 \\ Virginia W. Johns on, \\ "Many Leaves and Few \\ Grapes," 56:8-18. \\ 1878 \\ Mrs. Frank M'Carthy, \\ "Miss Truepenny's \\ Fortieth Christmas," \\ $56: 265-72$. \\ Alice Perry, "Helen," \\ 58:97-106.
}


Constance Fenimore

Woolson, "Anne,"

$62: 28-45$.

\section{3}

Mrs. H. M. Plunkett,

"The Rosary of Hearts,"

$66: 235-42$.

Edward Everett Hale,

"Dick's Christmas,"

$66: 275-80$.

1884

"A Working Girl,"

"Cassie's Christmas

Box," 68:305-12.

E.P. Roe, "Nature's

Serial story," 70:

56-71.

\section{5}

Elizabeth Stuart

Phelps, "The Madonna

of the Tubs," 72:95-

114.

*Charles Egbert

Craddock, "Way Down

in Lonesome Cove," 72 :

128-46.

"Fanny Albert Doughty,

$72: 166-68$.

\section{6}

* Thomas Nelson Page,

"Polly: A Christmas

Recollection," 74:37-52. 
Capt. Charles King, Sarah Orne Jewett, "Captain Santa
Claus," 76:107-20. "Law Lane," 2:725-42. 1888

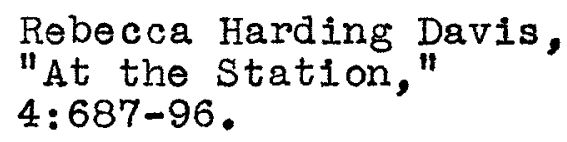

1889

*Ruth McEnery Stuart,

"A Golden Wedding,"

$80: 60-75$.

1890

Paul Heyse, "A

Christmas Present,"

$82: 16-38$.

1891

William McLennan,

"La Messe de M1nuit: A Christmas Legend," 84:142-47. *Henry van Dyke, "The
Oak of Geismar," 10: 681-87.

\section{2}

Constance Fenimore Woolson, "Christmas Party," 86:4057.

Eva Wilder McGlasson, "Fan's Manmy," 86: 76-85.

Ferdinand Fabre, "Le R6vilion: a Christmas Tale," 86:85-115. 
ATLANTIC MONTHLY HARPER'S MAGAZINE SCRIBNER'S MAGAZINE

$$
\begin{aligned}
& \text { *Thomas Nelson Page, } \\
& \text { "Charlie Whitter's } \\
& \text { Christmas Party," } \\
& 86: 155-57 \text {. } \\
& 1893 \\
& \text { J. Iincoln Steffens, } \\
& \text { "Sweet Punch: A } \\
& \text { Monologue," 88:126-29. } \\
& \text { *Thomas Nels on Page, } \\
& \text { "Rachel's Lovers," } \\
& \text { 88:158-61. } \\
& \text { *Henry van Dyke, "The } \\
& \text { Story of the Other } \\
& \text { W1se Man," 86:277-82. }
\end{aligned}
$$

\section{4}

Harriet Lewis Brad- Harriet Prescott

ley, "The Christmas Spofford, "The ColoAngel," 74:777-89. nel's Christmas,"

$90: 109-20$.

Hayden Carruth, "The Premature Prodigal," $90: 165$.

1900

Eliza Orme White, "A L1ttle Change," 86: $832-43$.

*Bierne Lay, "Whar My Chris'mus?" $90: 749-55$.

Norman Duncan, "Santa Claus at Lonely Cove," $92: 742-49$. 
ATLANTIC MONTHLY HARPER'S MAGAZINE SCRIBNER'S MAGAZINE

\section{4}

Elizabeth Jordan,

"The Surrender of

Professor Seymour,"

$109: 955-64$.

1905

Wm. John Hopkins,

"A Daughter of the

Rich," $96: 736-49$.

Winfield Scott Moody,

"Révilion," 38:678-92.

\section{7}

Fanny Kemble

Johns on, "The Big

Trouble and the

Iittle Boy," 100:

Marie Van Vorst,

"Bulstrode Changes

His Mind," 114:221-30.

758-63.

\section{8}

Mary Glascock, "The Howard Pyle, "The

Señor's Vigil," Mysterious Chest,"

102:250-57. 118:3-18.

Henry C. Rowland,

"The Poor," 102:728-

37.

Edith Wyatt, "A Beg-

gar's Christmas; a

Fable," 102:845-50.

1909

* Marjorie L. C. Pickthall, "The Worker in Sandalwood," 104:786-89.

James A. B. Scherer,

"How Christmas Came

Into England," 46:

641-51.

$\mathrm{Nels}$ on Iloyd, "A Christmas of Christmases," 46:693-702. 
ATLANTIC MONTHLY HARPER'S MAGAZINE SCRIBNER'S MAGAZINE

Bradley Gilman, "The McDermott Twins," $46: 741-49$.

1910

*Henry van Dyke, "The

Mansion," 122:3-17.

Margarita spalding

Gerry, "The Gift-

Bearer," 122:58-65.

Amelie Rives, "Her

Christmas Cabby,"

122:94-107.

1911

*Charles Egbert

Craddock, "His

Norman Duncan,

Barry Benefield, "0ld

Christmas Miracle,"

108: $767-75$.

Foundling," 122:

298-308.

Inez Haynes Gillmore,

"The Homeliest Child,"

124: 93-96.

1912

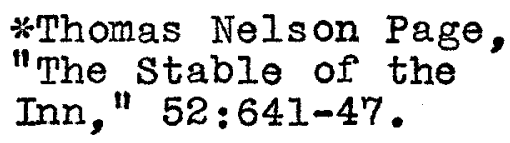

1913

Norman Duncan; "A

$126: 165-75$.

Richard Washburn

Child, "The story of

Alpheus Motley,"

126:188-99. 
Vale Downie, "Robin. John Galsworthy, "A the Bobbin," 130: Simple Tale," 56: 39-53. $735-41$.

1916

Georgia Wood Pangborn, "The Return," 134 : $4 I-47$.

\section{7}

Margarita Spalding Temple BaileJ, "The Gerry, "A Midwin- Red Candle,"62:684ter Night's Dream," 92 . 136: $82-94$.

\section{8}

Elsie Singmaster, "The Golden Mountain," 138:46-52.

1919

*Mary E. Wilkins Katharine Holland

Freeman, "The Gos- Brown, "The Very Anxpel According to ious Hother," 66:749Joan," 140:77-88. 52.

1920

Charles Caldwell Blair Niles, "Candles Dobie, "Christmas of Faith," 68:725-34. Cakes," 140:200-08.

\section{1}

* Eleanor C. Gibbs, Laura Spencer "Cunjur and 'Suasion: Plantation Portor "Romance," Harriet Welles, "The Chronicles," 128: 144:104-08. Runaway Blimp," 70: 689-701. $761-70$. 
ATLANTIC MONTHLY HARPER'S MAGAZINE SCRIBNER'S MAGAZINE

\section{2}

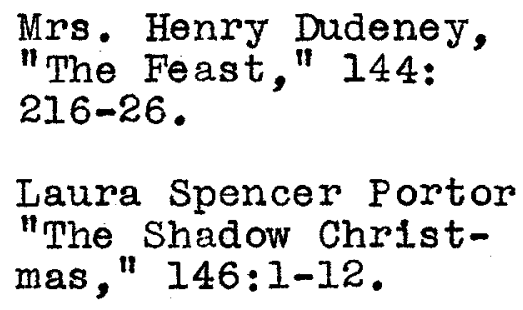

1923

Arthur Mas on, "The Prosper Buranelli, Donkeyman's Christ- "Bright Snowflakes," mas," 132:751-57. 147:727-34.

1926

Keene Abbott, "Tree of Life," 138:762-68
Margharite Fisher Mclean, "The Lonesome Christmas Tree," $80: 646-55$.

1928

Booth James on, "The Professional Santa Claus," 84:720-28.

Kenneth Griggs Merrill, "Adeste, FIdeles," 84:729-32.

1929

Eugenie Courtwright,

"Yours Lovingly,"

$144: 806-17$

1930

Roark Bradford, "How

Come Christmas: A Modern Morality," $162: 45-49$. 
Bernhard Johann Tüting, "The Family Chronicle," 148: 785-90.

\section{5}

Jo Pagano, "Signor Santa," 156:651-58.

\section{6}

Henry Williams on, Dorothy Thomas, "The "A Crown of Life," Home Place: "Christ157:77-85. mas Horning," 172: 210-24.

1937

*Genevieve Chandler, "De Wind an' de Tide," 102: $14-18$.

1938

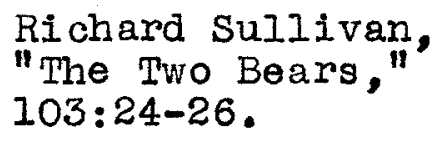


BIBLIOGRAPHY 


\section{BIBL IOGRAPHY}

\section{PRIMARY SOURCES}

Allen, James Lane, The Bride of the Mistletoe. New York: The Macmilian Company, 1909 . $190 \mathrm{pp}$.

The Doctor's Christmas Eve. New York: The MacmIlian Company, 1910. $304 \mathrm{pp}$.

- The Last Christmas Tree, an IdyI of Immortality. Portland, Me.: Thomas Bird Mosher, 1914. $38 \mathrm{pp}$.

Chandler, Genevieve, "De Wind an' de Tide;" Scribner's Magazine, 102 (December, 1937), 14-18.

Cooper, James Fenimore, The Pioneers; or, The Sources of the Susquehanna [published 1836]. New York: D. Appleton \& Company, 1879. Chaps. 1-19.

Dickens, Charles, "A Christmas Dinner," in Sketches by Boz [published 1836]. New York: Charles Scribner's Sons, 1902. I, 257-62.

The P1ckwick Papers [published 1837]. New York: Thomas $Y$. CroweII \& Company, n. d. I, 415-38, II, i-25.

A Ghristmas Carol [published 1843], in Christmas Books. London: Chapman \& Hall, Ld., n. d. Pp. 9-98. The Haunted Man and the Ghost's Bargain [published 1848 ], in Christmas Books. Pp. 411-525.

"Seven Poor Travelers" [published 1854], in Christmas stories. N. p., n. d. Pp. 79-91.

Doughty, Fanny Albert, "A Christmas Lament," Harper's Magazine, 72 (December, 1885), 166-68.

Fox, John, Jr., "Christmas Eve on Lonesome," in Christmas Eve on Lone some and Other Stories. New York: Charles Scribner's Sons, 1904. Pp. 3-13.

Freeman, Mary E. Wilkins, "Christmas Jenny," in A New England Nun and other Stories. New York: Harper and $\frac{\text { Brothers, }}{189}$ 1891. Pp. 160-77. $321-37$.

"A Stolen Christmas," in A New England Nun. Pp. 
Freeman, "A Church Mouse," in A New England Nun. Pp. 407-26. , "Young Lucretia," in Young Iucretia and Other Storles. New York: Harper and Brothers, 1893. Pp. I-I9.

"The Christmas Sing in our Village," in The People of Our Neighborhood. New York: International Assoc1atIon of Newspapers and Authors, 1901. Pp. 125-35.

, "The Givers," in The Givers. New York: Harper and Brothers, 1904. Pp. 3-50.

, "Lucy," in The Givers. Pp. 51-92.

, "Joy," in The Givers. Pp. 132-55.

, "The Reign of the Doll," in The Givers. Pp. 156-91.

228. "The Chance of Araminta," in The Givers. Pp. 192-

,"The Last Gift," in The Givers. Pp. 266-96.

, "The Gospel According to Joan," Harper's Magazine,

140 (December, 1919), 77-88.

Gibbs, Eleanor C., "Cunjur and ISuasion: Plantation Chronicles," The Atlantic Monthly, 128 (December, 1921),

Harte, Bret, "Dickens in Camp," in Poems (Boston: James R. Osgood and Company, 1871). Pp. 32-35.

"How Santa Claus Came to Simpson's Bar," The Atlantic Monthly, 29 (March, 1872), 349-57.

Hawthorne, Nathaniel, "Fancy's Show-Box: A Morality," in Twice-Told Tales [published 1837, 1842]. Boston:

Hought on inflin Company, 1882. Pp. 250-5\%.

, "The Christmas Banquet," In Mosses from an Old Manse [published 1846]. Boston: Houghton Mifflin Tompany, 1882. Pp. 322-46.

The Heart of Hawthorne's Journals, Newt on Arvin, editor. Boston: Houghton Miffin Company, 1929.

English Note Books, in Works. Boston: Hought on MIffin Company, 1898. VII, 408-588; VIII. 
Irving, Washington, A History of New-York $\cdot \cdot \cdot$ by Diedrich Knickerbocker [pubIished I809]. New York: G. P. Putnam \& Co., 1857 .

The Sketch-Book of Geoffrey Crayon, Esq. London: John Murray, I834. II, 1-89. -- The Sketch Book of Geoffrey Crayon, Gent. New York: G. P. Putnam \& Co., 1857. Pp. 233-98, et passim. [Published 1819-20]

Lay, Blerne, "Whar My Chris'mus?" The Atlantic Monthly, 90 (December, 1902), 749-55.

Murfree, Mary Noaflles ("Charles Egbert Craddock"), "Way Down in Lonesome Cove," Harper's Magazine, 72 (December, $1885), 128-46$.

"His Christmas Miracle," The Atlantic Monthly, 108 (December, 1911), 767-75.

Page, Thomas Nelson, "Polly: A Christmas Recollection," Harper's Magazine, 74 (December, 1886), 37-52. Also published in book form, Polly: A Christmas Recollection. New York: Charles Scribner's Sons, 1894. 49 pp.

, "Charlie Whittler's Christmas Party," Harpor's MagaZine, 86 (December, 1892), 155-57. Also included in Pastime Stories. New York: Charles Scribner's Sons, 1898.

"Rachel's tovers," Harper's Magazine, 88 (December, 1893), 158-61. Also included in Pastime Stories.

"My Cous in Fanny," in The Burial of the Guns. New York: Charles Scribner's Sons, 1894. Pp. 3-40.

"How the Captain Made Christmas," in The Burial of the Guns. Pp. 147-72.

A Captured Santa Claus. New York: Charles

Scribner's Sons, 1902. $81 \mathrm{pp}$.

"The Stable of the Inn," Scribner's Magazine, 52

(Décember, 1912), 641-47.

The Shepherd Who Watched by Night. New York:

Charles Scribner's Sons, 1916. 39 pp.

Pickthall, Marjorie L. C., "The Worker in Sandalwood," The Atlantic Monthly, 104 (December, 1909), 786-89. 
Porter, William Sidney ("0. Henry"), "The Gift of the Magi," in The Four Mililion. Doubleday, Page \& Company, 1903. $\mathrm{Pp} . \overline{16}-\overline{25}$.

"Christmas by Injunction," in Heart of the West. Garden City: Doubleday, Doran \& Company, Inc., 1904, 1935. Pp. 270-86.

"Whistling Dick's Christmas Stocking," in Roads of De'stiny. New York: Doubleday, Page \& Company, 1910. Pp. 3II-34.

"A Chaparral Christmas Gift," in Whirligigs. New York: Doubleday, Page \& Company, 1910. Pp. 223-30.

"An Unfinished Christmas Story," in Rolling Stones. Doubleday, Page \& Company, 1910. Pp. 223-30.

Riis, Jacob, Christmas Stories. New York: The Macmillan Company, 1897, 1923. $190 \mathrm{pp}$.

"A Story of Today," The Atlantic Monthly, 8 (October, Novem-

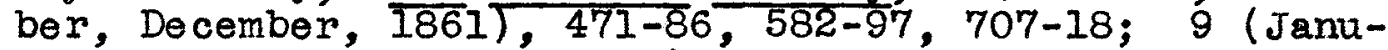
ary, February, March, 1862), 40-51, 202-13, 282-98.

Stuart, Ruth McEnery, "A Golden Wedding," Harper's Magazine, 80 (December, 1889), 60-75.

van Dyke, Henry, God and Iittle Children; New York: Ans on D. F. Randolph and company, 1890. il pp.

"The Oak of Geismar," Scribner's Magazine, 10 (December, 1891), 681-87. Also published in book form, The First Christmas Tree. A Story of the Forest. New York: Charles Scribner's Sons, $1897, \frac{19}{19} 14.76 \mathrm{pp}$.

"The Story of the Other Wise Man," Harper's Magazine, 86 (January, 1893), 277-82. Also published in book form, The Story of the Other Wise Man. New York: Harper and Brothers, 1895,1923 . 77 pp.

"The Lost Word," in The Blue Flower. New York: Charles Scribner's Sons, 1898. Pp. 209-57.

"The Mansion," Harper's Magazine, 122 (December, 19io), 3-17. Also included in The Unknown vuantity. New York: Charles Scribner's Sons, 1912. Pp. 325-70. 
van Dyke, "The Sad Shepherd," in The Unknown wuantity. Pp. $287-322$.

, The Lost Boy. New York: Harper and Brothers, 1913. AIso called "The Boy of Nazareth Dreams," in The Valley of Vision. New York: Charles Scribneris Sons, 1919. $\overline{\mathrm{PD}}, \overline{259-306 .}$ "The Hero and Tin Soldiers," in the Valley of
Vion. Pp. 23I-36.

"Let Us Go Even Unto Bethlehem," Delineator, 111 (Dé cember, 1927), 6-9, 75-76. 
Arvin, Newton, Hawthorne. Bostion: Little, Brown and Company, 1929.

Boynton, Henry Walcott, James Fenimore Cooper. New York: The Century Company, 1931.

Canby, Henry Seidel, The Short Story in English. New York: Henry Holt \& Company, 1909. Chaps. 10-14.

Cavert, Samuel McCrea, and Henry Pitney Van Dusen, editors, The Church Through Half a Century. New York: Charles Scribner's Sons, 1936.

Chesterton, G. K., Charles Dickens, a Critical Study. New York: Dodd Miead \& Company, I9o6. Chap. 7, et passim.

Curtis, George William, "Washington Irving," in Iiterary and Social Essays. New York: Harper \& Brothers, 1894, 1904. Pp. 239-93.

Forster, John, The Iife of Charles Dickens. New York: Charles Scribner's Sons, 1902. 2 vols.

Gorman, Herbert, Hawthorne, a Study in Solitude. New York: George H. Doran Company, 1927.

Hellman, George S., Hashingt on Irving, Esquire; Ambassador at Large from the New World to the 0ld. New York: Alf red A. Knopf, 1925 .

Kitton, Frederic George, Charles Dickens: His Life, Writings and Personelity. London: T. C. \& E. C. Jack, 1906 .

Knight, Grant C., American Literature and Culture. New York: Ray Long and Kichard R. Smith, Inc., 1932.

James Lane Allen and the Genteel Tradition. Chapel Hili: The University of North Carolina Press, 1935.

Leacock, Stephen, The Greatest Pages of Charles Dickens. Garden City: Doubleday Doran \& Company, Inc., 1934. Chap. 5. 
[Lunn], Hugh Kingsmill, The Sentimental Journey; a Life of Charles Dickens. New York: William Horrow \& Co., 1935.

Marcosson, Isaac, Adventures in Interviewing. New York: John Lane Company, 1925.

Maurois, André, Dickens, Hamish Motes, translator. New York: Harper and Brothers, 1928.

Mitford, Mary Russell, "Uur Village," in Works. Philadelphia: James Crissy, 1841. Pp. 7-306.

Pattee, Fred Lewis, The First Century of American Iiterature: 1770-1870. New York: D. Appleton-Century Co., 1935.

"On the Terminal Moraine of New England Puritanism," in' Side-Lights on American Literature. New York: "The Century Co., 1922. Pp. 175-209.

Sharpe, Dores Robins on, Walter Rauschenbusch. New York: The Macmillan Company, 1942.

Stewart, George Rippy, Jr., Bret Harte, Argonaut and Exile. Bost on: Hought on Miffin Company, 1931 .

Van Doren, Carl, The American Novel. New York: The Macmilian Company, 1921.

van Dyke, Tertius, Henry van Dyke: A Biography. New York: Harper and Brothers, 1935.

Wilkins, William Glyde, Charles Dickens in America. New York: Charles Scribner's Sons, 1912. Chaps. 5 and 6.

Williams, Stanley T., The Life of Washington Irving. New York: Oxford University Press, 1935. 2 vols.

Wright, Thomas, The Iife of Charles Dickens. New York: Charles Scribner's Sons, 1936. 


\section{B. PERIODICAL ARTICLES}

Branch, E. Douglas, "Jingle Bells: Notes on Christmas in American Iiterature," Saturday Review of Literature, 17 (December 4, 1937), 3-4, 20, 24, 28.

[Curtis, George William], "The Editor's Eqsy Chair," Harper's Magazine, 52 (January, 1876), 290-91.

"The Editor's Easy Chair," Harper's Magazine, 60 (January, 1880), 302-03.

Knight, Grant C., "Allen's Christmas Trilogy and Its Meaning," The Bookman, 68 (December, 1928), 411-15.

Macy, John, "Charles Dickens, Household Word," The Bookman, 68 (December, 1928), 420-28. 


\section{APPENDIX}

, 
CORRESPONDENCE WITH GRANT C. KNIGHT

AND TERTIUS VAN DYKE

Louisville, Kentucky

February 2i, 1943

Dr. Grant C. Knight

Montclair

Lexington, Kentucky

Dear Dr. Knight:

In the preparation of a thesis on the subject of the American Christmas story, I have become interested--perhaps disproportionately so--in James Lane Allen's Christmas Trilogy.

Although your treatments of this work, both in the biography and in The Bookman for December, 1928, have helped to make It intelligible, other questions continue to present themselves; and some of these I am bringing before you in the hope that you may have some information, or some theory, which you will be willing for me to use.

1. What factor in Allen's Iife could explain the seriousness with which he regarded Christmas?

2. Early in the biography, in listing about a dozen elements of the Kentucky scene at the time of Allen's birth, you mention ".. Christmas festivities when the entire land was blue with the smoke from smokehouses." Was this list based on internal evidence taken from the novels, or had you extermal sources also?

3. Is it an exaggeration to claim that the personified use of trees, especially of evergreens, is almost an obsession with the author?

4. Assuming that this was an idée fixe, could the following phrase, found in this connection (The Heroine in Bronze, p. 235), bo a valid clue: "The human heart trying to reach other hearts through images not human"?

5. Again assuming the validity of Nos. 3 and 4 , why should 
the evergreen have been selected as his favorite "image"? (And that, perhaps, would suggest the answer also for No. 1)

6. This may be mere curiosity, but was it you who discovered the "Rosetta Stone"--the outline and the Eve-legend clipping?

If you can furnish information along these or other lines, or if you will point out those instances in which my interpretation is at fault, I shall be very grateful indeed.

Yours very truly,

KATHARINE A. SEE

University of Kentucky Lexington

$1 \mathrm{March}, 1943$

Dear Miss See,

I should be wary of a statement that had James Lane Allen. obsessed with evergreen trees, and even more wary about making such a declaration. It seems to me that it is hardly necessary to believe that a tree was to him an obsession, a phallic symbol, a racial memory, or anything else of that sort. Last week my younger daughter wrote me: "When I was tiny, whenever I was angry or hurt, I used to run and climb way up in a big tree, and let it rock me, and play with the soft little green leaves, and talk to it. Trees are very understanding." My guess is that Allen's thoughts of trees were no more or less morbid than those of any one else who associates them with childhood experiences. Allen was, you remember, a lonely child, and trees were doubtless among his understanding friends.

However, as I tried to make plain in the biography, he was so reticent a person that I do not pretend to read his secrets.

My sentence about Christmas festivities was adapted, if I remember correctly, from one of his attempts to write an autoblography. I doubt whether he regarded the holiday with any more seriousness than the average individual. Perhaps 
he was in this instance, as in others, more ceremonious than most. If he thought of Christmas in connection with any significant event in his own life, I do not know what that event was.

Yes, I discovered and have the "Kosetta Stone." When next you come to Lexington I hope you will let me know, so that we may meet, talk over your work and Mr. Allen, and look at the "Stone." Meanwhile $\perp$ wish you the best fortune with your thesis and regret that you are not writing it for me. Let me know if I can help you in other particulars--not that I was of any help in this instance!

Faithfuliz yours,

GRANT C. KNIGHT

Louisville, Kentucky
February 20, 1943

Reverend Tertius van Dyke

Washington, Connecticut

Dear Mr. van Dyke:

In the preparation of a thesis on the subject of the American Christmas story, I am naturally giving much attention to the Story of the other Wise Man and other Christmas stories by Henry van Dyke.

I have received much belp from your blography of Henry van Dyke. However, other questions continue to present themselves; and these I am bringing before you in the hope that you may have some information which you will be wllling for me to use.

1. I gather that Henry van Dyke in childhood and youth enjoyed a happy and tolerant home life. Have you heard it sald whether there was any special emphasis on the celebration of Christmas which would help to explain his later interest in the day?

2. More specifically, was there in the home an emphasis on the religious observance of Christmas? 
3. If Christmas did receive prominence in that home, do you think such observance could be traced to Dutch tradition in the family?

4. The Enclyclopaedia of the Presbyterian Church (Philadelphia: Pres byterian Publishing Company, 1884), In its sketch of Henry Jacks on van Dyke, Senior, lists among his published sermons one entitled "Politics for Christmas." Do you know anything about the nature of this sermon--whether it was pro-Christmas, anti-Christmas, or what attitude it represented? ( $I$ am writing also to the Westminster Press to Inquire whether this could have been one of that Board's publications, and, if so, whether there is a copy extant.)

5. In the Preface to The Story of the Other Wise Man it is stated of the hero: "His countenance was as clear as the memory of my father's face." Do you know whether your father pictured Artaban as actually resembling your grandfather?

I shall be very grateful for any help you may be willing to give mo, along these or any other lines.

Yours very truly,

KATHARINE A. SEE

Avalon Cottage

Princeton, N. J. $\mathrm{Feb}$. 25, 1943

Dear Madam:

Your letter of Feb. 20 is forwarded to me here. Will you forgive a brief reply written in an evening hour, when $I$ am free from my duties in the University? My brevity is dictated by necessity and not lack of interest. I answer your questions as numbered in your letter:

1. My father certainly enjoyed a happy and tolerant home Iife as a child and youth as is indicated in the biography which I wrote. Christmas was regularly celebrated in his father's family but I believe what you call "his interest 
in the day" sprang rather from conviction about the importance of the person whose birthday it records than from chlldish memories of festivals. As you may gather from the biography both my father and his were strong believers in Christ.

2. The chief emphasis in the home was undoubtediy on the religious observance of Christmas though I believe when my father was a child the observance was a home and not a church observance among the Presbyterians unless Christmas fell on a Sunday.

3. The Dutch tradition celebrates St. Nicholas Day which is not Christmas at all. But the good will and the conferring of gifts and assembling of families is the same in any case. Dates are not as vital as spiritual relationship.

4. I am sorry I cannot answer this question. You might find the sermon in the union Seminary library, New York City.

5. I never heard my father say that he pictured Artaban as actually resembling his father. Nor do I think that the quotation indicates it. As you know my father had a great and continuing admiration and affection for his father as I also have for mine. No doubt any man's admiration tends to become centred in one person but I know of no grounds for identifying the two personalities.

I hope the above may be of help to you.

Sincerely yours,

TERTIUS VAN DYKE 